\title{
An introduction to the SCOUT-AMMA stratospheric aircraft, balloons and sondes campaign in West Africa, August 2006: rationale and roadmap
}

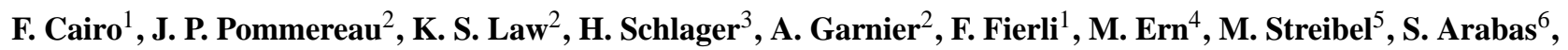
S. Borrmann ${ }^{7,8}$, J. J. Berthelier ${ }^{2}$, C. Blom ${ }^{9}$, T. Christensen ${ }^{10}$, F. D'Amato ${ }^{11}$, G. Di Donfrancesco ${ }^{12}$, T. Deshler ${ }^{13}$, A. Diedhiou ${ }^{14}$, G. Durry ${ }^{15}$, O. Engelsen ${ }^{16}$, F. Goutail ${ }^{2}$, N. R. P. Harris ${ }^{5}$, E. R. T. Kerstel ${ }^{17}$, S. Khaykin ${ }^{18}$, P. Konopka ${ }^{4}$, A. Kylling ${ }^{16}$, N. Larsen $^{10}$, T. Lebel ${ }^{14}$, X. Liu ${ }^{15}$, A. R. MacKenzie ${ }^{19}$, J. Nielsen ${ }^{10}$, A. Oulanowski ${ }^{18}$, D. J. Parker ${ }^{20}$, J. Pelon ${ }^{2}$, J. Polcher ${ }^{21}$, J. A. Pyle ${ }^{22,29}$, F. Ravegnani ${ }^{1}$, E. D. Rivière ${ }^{15}$, A. D. Robinson ${ }^{22}$, T. Röckmann ${ }^{23}$, C. Schiller ${ }^{4}$, F. Simões ${ }^{2}$, L. Stefanutti ${ }^{24,25}$, F. Stroh ${ }^{4}$, L. Some ${ }^{26}$, P. Siegmund ${ }^{27}$, N. Sitnikov ${ }^{18}$, J. P. Vernier ${ }^{2}$, C. M. Volk ${ }^{28}$, C. Voigt ${ }^{3,7}$, M. von Hobe ${ }^{4}$, S. Viciani ${ }^{11}$, and V. Yushkov ${ }^{18}$

${ }^{1}$ Istituto di Scienze dell' Atmosfera e del Clima ISAC-CNR , Consiglio Nazionale delle Ricerche, Italy

${ }^{2}$ LATMOS, CNRS, Université de Versailles St-Quentin, Université Paris 6, France

${ }^{3}$ Deutsches Zentrum für Luft- und Raumfahrt, Institut für Physik der Atmosphäre, Oberpfaffenhofen, Germany

${ }^{4}$ ICG-1, Forschungszentrum Jülich, Jülich, Germany

${ }^{5}$ European Ozone Research Coordinating Unit, Cambridge University, Cambridge, UK

${ }^{6}$ Institute of Geophysics, University of Warsaw, Warsaw, Poland

${ }^{7}$ Institute of Atmospheric Physics, University of Mainz, Mainz, Germany

${ }^{8}$ Max-Planck Institute for Chemistry, Particle Chemistry Department, Mainz, Germany

${ }^{9}$ Institut für Meteorologie und Klimaforschung (IMK), Forschungszentrum Karlsruhe und Universität Karlsruhe,

Karlsruhe, Germany

${ }^{10}$ Danish Meteorological Institute, Copenhagen, Denmark

${ }^{11}$ Istituto Nazionale di Ottica, Consiglio Nazionale delle Ricerche, Firenze, Italy

${ }^{12}$ Ente Nazionale per le Nuove tecnologie, l'Energia e l'Ambiente, Frascati, Italy

${ }^{13}$ Department of Atmospheric Sciences, Wyoming University, Laramie, USA

${ }^{14}$ LTHE, Université J.Fourier, Institut de Recherche pour le Developpement-France, Grenoble, France

${ }^{15}$ Groupe de Spectroscopie Moléculaire et Atmosphérique, Faculté des Sciences, Université de Reims Champagne-Ardenne and CNRS, Reims, France

${ }^{16}$ Norwegian Institute for Air Research, Oslo, Norway

${ }^{17}$ Center for Isotope Research, University of Groningen, Groningen, The Netherlands

${ }^{18}$ Central Aerological Observatory, Moscow, Russia

${ }^{19}$ Lancaster Environmental Centre, Lancaster University, Lancaster, UK

${ }^{20}$ School of Earth and Environment, University of Leeds, Leeds, UK

${ }^{21}$ Laboratoire de Météoreologie Dynamique, CNRS, Paris, France

${ }^{22}$ Chemistry Department, Cambridge University, Cambridge, UK

${ }^{23}$ Institute for Marine and Atmospheric Research Utrecht, Utrecht University, Utrecht, The Netherlands

${ }^{24}$ Istituto di Ricerche per la Protezione Idrogeologica, Consiglio Nazionale delle Ricerche, Firenze, Italy

${ }^{25}$ Geophysica-EEIG, Firenze, Italy

${ }^{26}$ INERA, Ouagadougou, Burkina Faso 


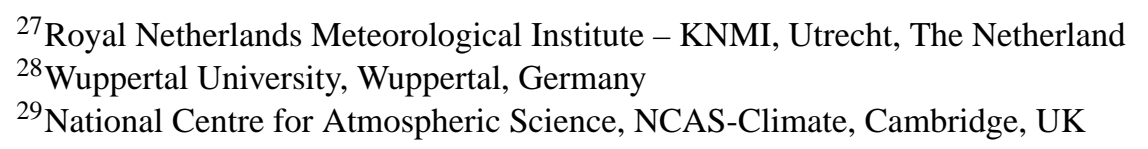

Received: 19 August 2009 - Published in Atmos. Chem. Phys. Discuss.: 23 September 2009

Revised: 12 February 2010 - Accepted: 18 February 2010 - Published: 3 March 2010

\begin{abstract}
A multi-platform field measurement campaign involving aircraft and balloons took place over West Africa between 26 July and 25 August 2006, in the frame of the concomitant AMMA Special Observing Period and SCOUT-O 3 African tropical activities.

Specifically aiming at sampling the upper troposphere and lower stratosphere, the high-altitude research aircraft M55 Geophysica was deployed in Ouagadougou $\left(12.3^{\circ} \mathrm{N}\right.$, $1.7^{\circ} \mathrm{W}$ ), Burkina Faso, in conjunction with the German D20 Falcon, while a series of stratospheric balloons and sonde flights were conducted from Niamey $\left(13.5^{\circ} \mathrm{N}, 2.0^{\circ} \mathrm{E}\right)$, Niger.

Altogether, these measurements were intended to provide experimental evidence for a better understanding of large scale transport, assessing the effect of lightning on $\mathrm{NO}_{\mathrm{x}}$ production, and studying the impact of intense mesoscale convective systems on water, aerosol, dust and chemical species in the upper troposphere and lower stratosphere. The M55 Geophysica carried out five local and four transfer flights between southern Europe and the Sahel and back, while eight stratospheric balloons and twenty-nine sondes were flown from Niamey.

These experiments allowed a characterization of the tropopause and lower stratosphere of the region. The paper provides an overview of SCOUT-AMMA campaign activities together with a description of the meteorology of the African monsoon and the situation prevailing during the flights and a brief summary of the observations accomplished.
\end{abstract}

Correspondence to: F. Cairo

(f.cairo@isac.cnr.it)

\section{Introduction}

Understanding the processes regulating the entry of tropospheric air into the stratosphere in the tropics is essential to assess how the stratosphere will evolve under climatic change and to deliver reliable estimates of the future ozone recovery.

The generally accepted view of troposphere to stratosphere transport in the tropics is a fast convective uplift to the level of maximum outflow of the Hadley cell at about $200 \mathrm{hPa}$, (Gettelman et al., 2002; Alcala and Dessler, 2002), and then slow ascent $(0.2-0.3 \mathrm{~mm} / \mathrm{s})$ by radiative heating across the Tropical Tropopause Layer (TTL) (Highwood and Hoskins, 1998). The TTL shares tropospheric and stratospheric characteristics between the level of zero net radiative heating (Gettelman et al., 2004; Corti et al., 2005) and that of the cold point, or of the maximum altitude influenced by the troposphere around $70 \mathrm{hPa}$ as suggested by Fueglistaler et al. (2009). A still-open question is how much fast convective overshooting of adiabatically cooled tropospheric air well above the tropopause, then mixing with stratospheric air, as proposed by Danielsen (1982, 1993), contributes to the composition of the lower stratosphere.

From past observations above oceanic regions, where most high-altitude aircraft and sonde measurements are available, such overshooting events are generally assumed to be rare and therefore their contribution unimportant on a global scale.

However, as shown by the geographic distribution of overshooting features seen by the Precipitation Radar (PR) and of flashes seen by the Lightning Imaging Sensor (LIS) both on the Tropical Rainfall Measuring Mission (TRMM) satellite (Liu and Zipser, 2005), convective overshooting is by far more frequent and intense over tropical land areas where few observations are available, than over oceans. Furthermore, according to Zipser et al. (2006), most extreme events are occurring over Africa, in the equatorial region during the Northern Hemisphere winter and in the Sahel in the summer, where in situ measurements in the TTL were totally absent.

Though not yet in Africa, some aspects of the impact of tropical continental convection on the UTLS have been already explored during the EU funded projects HIBISCUS (Pommereau et al., 2007; Nielsen et al., 2007) and 
TROCCINOX (Chaboureau et al., 2007; Corti et al., 2008) balloon and high-altitude M55 aircraft campaigns in Brazil in 2004-2005 and during the SCOUT-O 3 M55 aircraft deployment in Northern Australia (http://www.ozone-sec.ch.cam. ac.uk/scout_o3/) (Schiller et al., 2008; Corti et al., 2008).

Among their results is the observation of fast uplift of adiabatic cooled tropospheric air and ice crystals across the tropopause over deep overshooting systems developing in the afternoon over land, resulting in the hydration, rather than the dehydration, of the lower stratosphere, a process successfully captured by Cloud Resolving Models (Chaboureau et al., 2007; Grosvenor et al., 2007). Although the impact of such land systems on the global scale is still unclear, there are indications from zonal distributions of tropospheric tracers, such as $\mathrm{N}_{2} \mathrm{O}, \mathrm{CH}_{4}$ and $\mathrm{CO}$ observed by satellites, of an increase in the concentration of these species above the tropopause over land tropical areas during the convective season, particularly intense over Africa (Ricaud et al., 2007).

This scientific context motivated the choice of SCOUT$\mathrm{O}_{3}$ scientists to perform UTLS observations over the African continent. There, the international and EU supported African Monsoon Multidisciplinary Analysis (AMMA, http: //science.amma-international.org) (Redelsperger et al., 2006) project was planning a field campaign during the summer convective season of 2006, to characterize the West African monsoon. The common effort of the two projects thus offered the unique opportunity of extending the characterization of the atmosphere from the boundary layer to the lower stratosphere, during the convective period.

The present paper focuses on UTLS investigations, namely stratospheric ballons, sondes and M55 aircraft activities, largely built on the experience of the HIBISCUS and TROCCINOX projects that took place in February 2004 and 2005 in South-America (Pommereau et al., 2007; Huntrieser et al., 2008), and the SCOUT-O 3 M55 aircraft campaign in Darwin (Australia) in November-December 2005 (Brunner et al., 2009).

The paper is organized as follows: Sect. 2 is devoted to a description of the meteorology of the region associated with the monsoon, followed in Sects. 3 and 4 by a description of the aircraft and balloon payloads and flights. The conclusions in Sect. 5 provide indications to relevant papers where details of the results achieved during the campaign can be found.

\section{Meteorological background}

An overview of the monsoon mechanism in West Africa is given by Hall and Peyrille (2006), while a comprehensive analysis of the large and regional scales features of the summer 2006 monsoon, in relation to its interseasonal and interannual variability, can be found in Janicot et al. (2008). Here is a summary of the meteorology of West Africa in the summer and its evolution during the 2006 season at the time of the M55 and stratospheric balloons campaign, with emphasis on the upper troposphere and lower stratosphere.

The vast subsidence over the Sahara desert, stronger in winter and spring, is displaced in the summer to the SouthWest toward the Gulf of Guinea by the developing Walker circulation, triggered by the Indian Monsoon outflow. Still in the summer, the air over the Sahara is subsiding in the mid to high troposphere, while intense surface heating creates a "heat low" promoting surface convergence and low to mid tropospheric divergence. This ascending region is named the Saharan Air Layer (SAL). A meridional circulation is set up with dry, warm, dust laden northerly winds moving south, overriding the moist southerly winds from the Gulf of Guinea. The region of confluence of these two currents is named the Inter Tropical Front (ITF) and moves northward as the monsoon circulation becomes established. To the south, the Inter Tropical Convergence Zone (ITCZ) follows the ITF northward.

The average circulation pattern in the lowermost troposphere over the 1979-1999 period is reported in the leftmost panel of Fig. 1 (from Janicot et al., 2008), where the average positions of ITCZ and ITF in August are displayed; Monsoon surface south-westerly winds are visible over the whole Guinea Gulf and penetrate in the Sahelian area, while persistence of monsoon circulation north of $10^{\circ} \mathrm{N}$ is especially visible east of $0^{\circ} \mathrm{W}$ meridian. Precipitation (not shown in the plot; see Fig. 1 in Sultan and Janicot, 2003) is located south of $15^{\circ} \mathrm{N}$.

A distinct feature of the African Monsoon is the presence of the dry and warm SAL capping the moist and relatively cool air from the Gulf of Guinea, between the ITF and the ITCZ, and thus inhibiting convection. Thus only relatively large scale systems are energetic enough to break through this air layer (Parker et al., 2005a). Hence in the Sahel, the majority of convection and rainfall is associated with large scale Mesoscale Convective Systems (MCS), forming over the Sahel and migrating westward with the mean flow. The frequency and existence of such organized large mesoscale systems represented one of the main drivers of our interest in the Sahelian region. As pointed out in Rossow and Pearl (2007), it is in fact likely that convective penetration of tropospheric air into the stratosphere is dominated by the larger, longer-lived, extreme tropical storms. Thus, MCS represent an optimal test bench for such a hypothesis.

The ascending branch of the Hadley cell is situated north of the equator in the summer. Upper level air moving south is deflected by the Coriolis force and acquires a westward component, forming the Tropical Easterly Jet (TEJ) at $16 \mathrm{~km}$ and at $10^{\circ} \mathrm{N}$ over the African continent and the Gulf of Guinea.

Another particular feature of the general circulation over West Africa is due to the peculiar thermal structure of the region, with surface temperatures increasing and midtropospheric temperatures decreasing northward. This induces an easterly vertical wind shear at lower levels, and a westerly wind shear above. The surface monsoon westerlies 

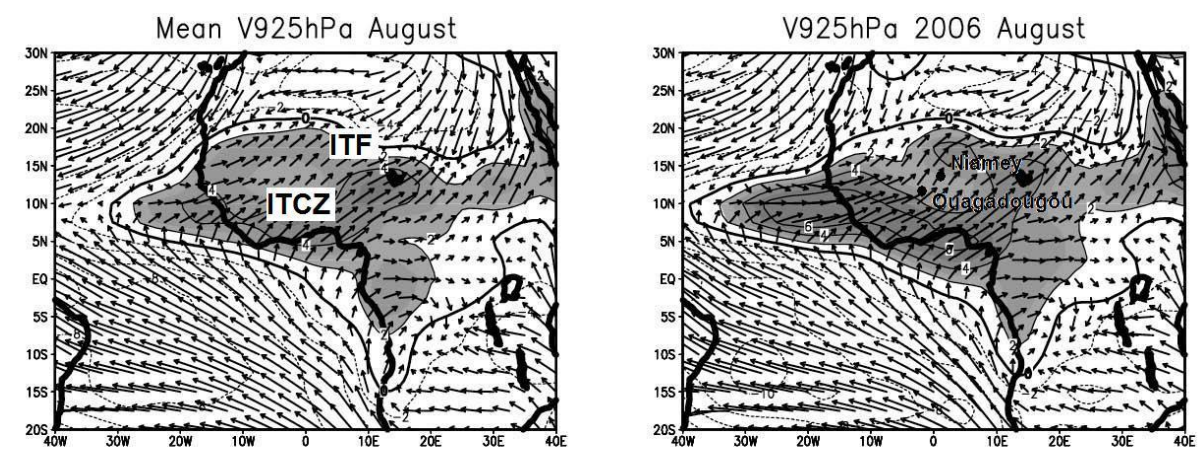

Fig. 1. Left, 1979-1999 average winds from NCEP at $925 \mathrm{hPa}$ in August. Right, same but for 2006. Shaded areas represents winds greater than $2 \mathrm{~m} / \mathrm{s}$ (from Janicot et al., 2008).

are thus overlain by easterlies peaking at about $650 \mathrm{hPa}$, forming a seasonal easterly jet named the African Easterly Jet (AEJ), located between $5^{\circ}$ and $15^{\circ} \mathrm{N}$. This is the region where the African Easterly Waves (AEW) develop near the jet level, modulating the monsoon variability and rainfall, and eventually providing precursors for tropical cyclones over the Atlantic ocean.

The monsoon starts during the second half of June, with the ITF moving northward and crossing $15^{\circ} \mathrm{N}$ while the ITCZ follows by the end of June. The peak zonal-mean rainfalls migrate rapidly north from the coast of the Gulf of Guinea to the Sahel in late June (Sultan and Janicot, 2000), and retreats more slowly back again in September, promoting two rainy seasons in the south and one in the north.

\subsection{The 2006 monsoon season}

The 2006 season was characterized by normal convective activity, although slightly delayed and higher in JulySeptember with respect to the mean, with excess rainfall in the northern Sahel.

Monsoon winds for August 2006 (Fig. 1, right panel) show a more pronounced westerly flow over the Atlantic ocean with respect to the 1979-1999 average and a less marked northward penetration in westernmost Africa while the position of the ITCZ do not differ significatively from the climatology. Also shown in Fig. 1, right panel, are the positions of the cities of Niamey and Ouagadougou - where the SCOUT-AMMA campaign activities took place, as detailed later. From these two cities, the entire ITCZ was within the range of observation, from the ITF up north to the coast of the Gulf of Guinea down south.

Monsoon onset occurred late with respect to the long term mean: the ITCZ moved north of $10^{\circ} \mathrm{N}$ during the second week of July. Periods of intense AEW activities happened during the second half of July and from 15 August through mid September. Events of dry extra-tropical air intrusions originating from the polar jet and subsiding to the mid troposphere were also documented, modulated by the AEW on a 10-20 day timescale and by the Madden-Julian Oscillation (MJO) activity over the Indian region on a 40-50 day timescale. These were observed mainly in June and July and during the third week of August.

Figure 2 shows the accumulated rainfall for 1-10 August 2006. During the third decade of July, significant rainfall occurred east of Sudan, on the border between Chad and the Central African Republic and over the coast of the Gulf of Guinea. Precipitation intensified and extended from southern Chad to Nigeria and Cameroon during the course of the first twenty days of August. In the relatively drier sub-saharan region, only the mountain ridges in N-E Mali, N-W Niger and $\mathrm{N}$ Chad received significant rainfall.

\subsection{Upper troposphere - lower stratosphere (UTLS)}

The average ECMWF reanalyzed wind speed $(\mathrm{m} / \mathrm{s})$ and direction (vectors) at 150 and $70 \mathrm{hPa}$ over Africa between $10^{\circ} \mathrm{S}$ and $30^{\circ} \mathrm{N}$ from 15 July to 16 August are shown in Fig. 3 where the TEJ can be seen with maximum intensity over East Africa. The wind speed decreases westwards being fully zonal at $5^{\circ} \mathrm{N}$ and diverging south and northwards.

A zonal wind vertical cross section along the $5^{\circ}$ E meridian is shown in Fig. 4. The low altitude AEJ is centred at $5^{\circ} \mathrm{N}$, while the TEJ axis shifts from $5^{\circ} \mathrm{N}$ at its lower levels around $200 \mathrm{hPa}$ to $15^{\circ} \mathrm{N}$ at $80 \mathrm{hPa}$.

The TEJ has a profound impact on the origin of airmasses in the West Africa Tropical Tropopause Layer (TTL). Figure 5 reports 10 days back-trajectories starting from the stratospheric aircraft flight paths calculated from ECMWF analysis with T512 spectral resolution. In the timeframe of the campaign, airmasses over the Sahel mainly came from the Asian tropical UTLS. The TEJ transported upper tropospheric air westward thus rendering the Sahelian TTL attractive for studing the long range impact of the South Asian monsoon. Deviations from zonal transport can be observed: (1) a large fraction of airmasses sampled in the uppermost troposphere ( 360 to $380 \mathrm{~K}$ ) originates from the Asian continent mid-latitudes and enters the TEJ after being entrained 


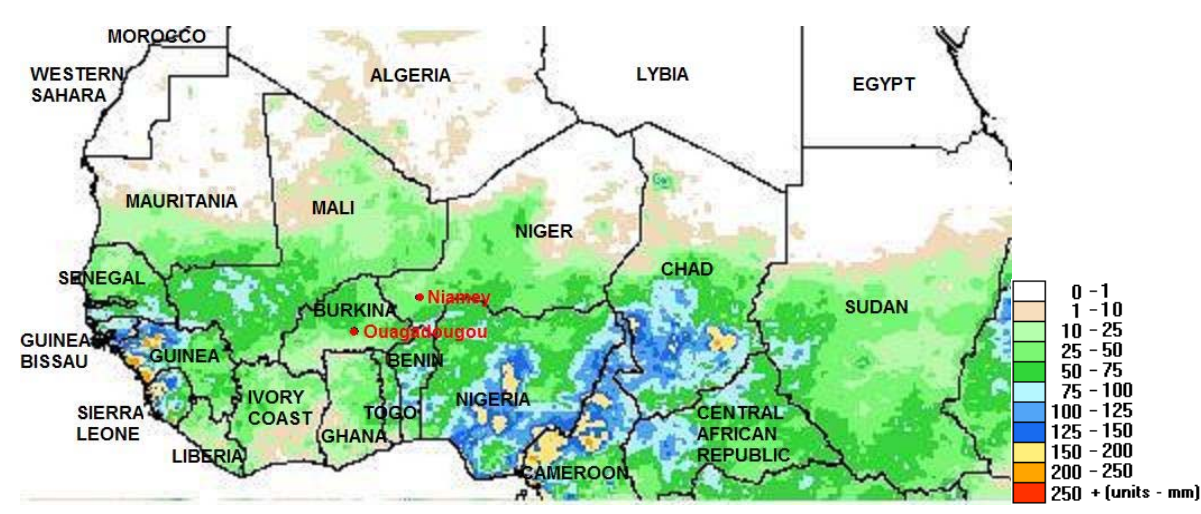

Fig. 2. Map of 1-10 August 2006 accumulated rainfall in West Africa (from the Goal of the Famine Early Warning Systems Network (FEWS NET) as a NOAA satellite imagery product (Tucker et al., 2005). Niamey and Ouagadougou are $400 \mathrm{~km}$ apart in the Sahel region.
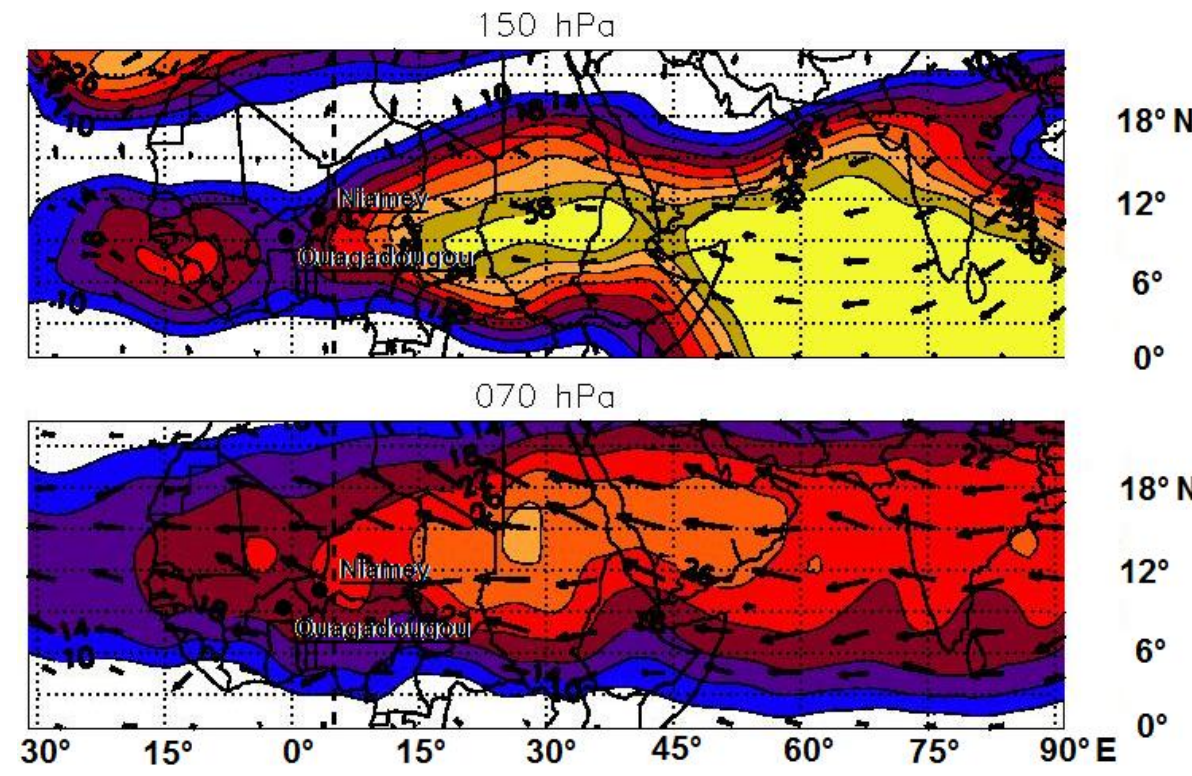

Fig. 3. ECMWF reanalyzed average wind module (m/s) and direction (vectors) between $15 \mathrm{July}-16 \mathrm{August}$ at $150 \mathrm{hPa}$ (Top) and $70 \mathrm{hPa}$ (Bottom). The dashed line shows the $5^{\circ}$ E meridian, used for a vertical cross section in Fig. 4.

in the Himalayan anticyclonic circulation and (2) airmasses observed in the southward legs of M55 flights comes from southern African continent. A detailed analysis of these pathways of transport is ongoing (Law et al., personal communication, 2009) while the impact of transport pattern (2) has been investigated by Real et al. (2009).

Also shown in Fig. 4 is the stratospheric westward phase of the Quasi Biennal Oscillation (QBO) at $50 \mathrm{hPa}$ at the equator and the sub-tropical and tropical westerly jets at $200 \mathrm{hPa}$ at $35^{\circ} \mathrm{N}$ and $10^{\circ} \mathrm{S}$ respectively.

A reversal of the QBO winds was occurring in the lower stratosphere at the time of the SCOUT-AMMA. The impact of Kelvin waves on the zonal average stratospheric temperature variance of ECMWF operational analyses within $15^{\circ} \mathrm{S}-$ $15^{\circ} \mathrm{N}$ is displayed in Fig. 6. The procedure for deriving the Kelvin wave component from the temperature variance employs a spectral analysis as outlined in Ern et al. (2008). The figure also shows the average ECMWF tropical zonal wind. The zero line separating east and west phase QBO is around $20 \mathrm{~km}$ during SCOUT-AMMA. The amplitude of Kelvin wave activity in the westerly phase is relatively small during 2006, while westward propagating equatorial Rossby waves are favoured. This is further illustrated in Fig. 7, showing the ECMWF temperature anomaly at $\left(13^{\circ} \mathrm{N}, 0^{\circ} \mathrm{E}\right)$ in July-August 2006 where the largest temperature fluctuations are observed in the TTL region, but not exceeding $2 \mathrm{~K}$ of amplitude. 


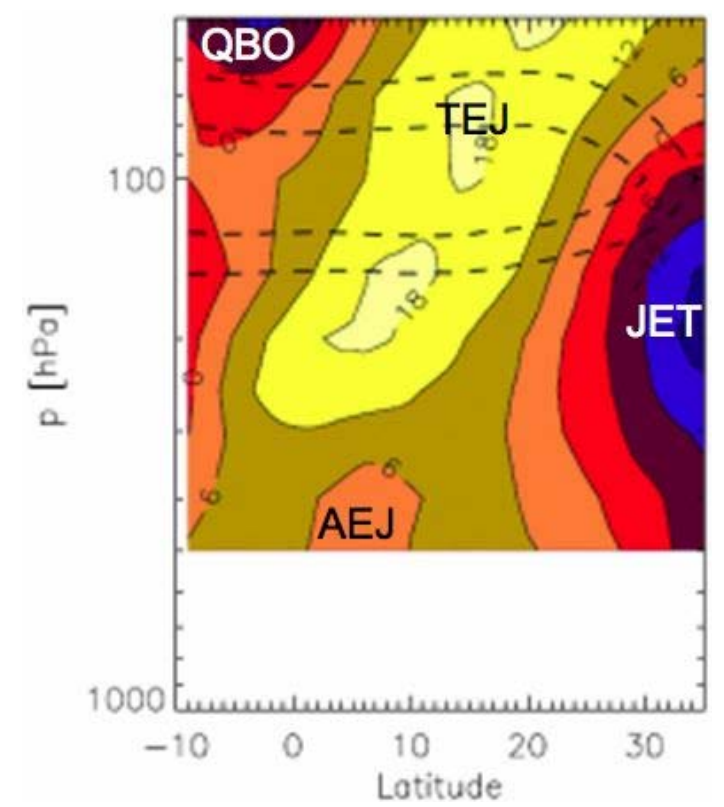

Fig. 4. 15 July-16 August average ECMWF reanalyzed zonal wind cross section along the $5^{\circ}$ meridian. Temperature levels at -67 and $-72{ }^{\circ} \mathrm{C}$ are overlaid as dashed thick lines.

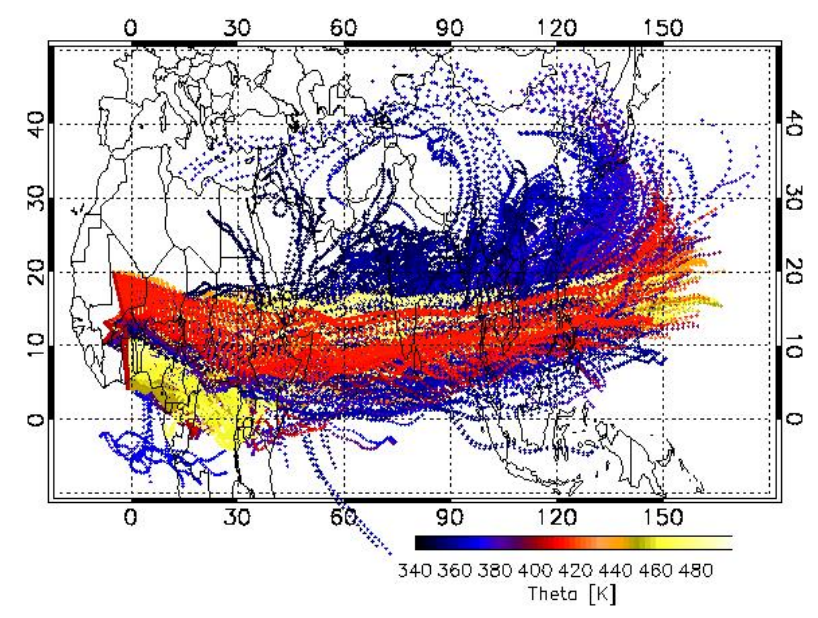

Fig. 5. 10 days backtrajectories starting from the M55 flight paths in the AMMA-SCOUT campaign. The red thick line shows the aircraft location. In the upper troposphere, below the $380 \mathrm{~K}$ level, the airmasses are coming from the Asian monsoon region, while at higher latitude in the lower stratosphere between 380-440 K, they remain at the same latitude coming from South Asia and the Pacific and equatorial Africa for the uppemost levels ( $\geq 440 \mathrm{~K})$.

The results of a space-time spectral analysis with band pass filters corresponding to different wave modes are shown in Fig. 8, where temperature anomalies attributed respectively to Kelvin, equatorial Rossby and Rossby-gravity waves are separated. Both Kelvin and Rossby wave ridges display descent (as expected), sometimes eliding each other.

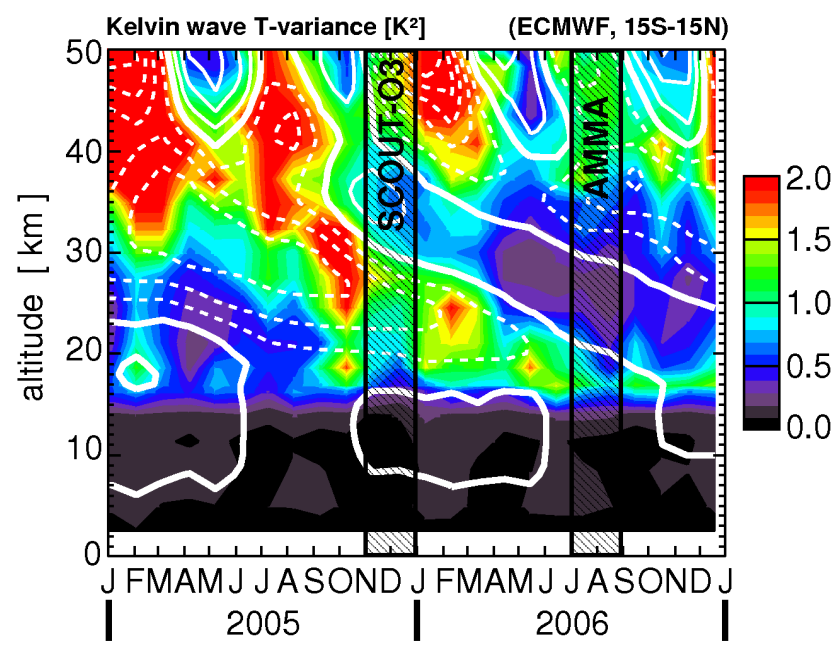

Fig. 6. Time series of $15^{\circ} \mathrm{S}-15^{\circ} \mathrm{N}$ average total Kelvin wave temperature variance derived from ECMWF operational analyses (colour code in $\mathrm{K}$ ). Also shown are the $15^{\circ} \mathrm{S}-15^{\circ} \mathrm{N}$ average ECMWF zonal winds (white contours, contour increment is $10 \mathrm{~m} / \mathrm{s}$ ). The solid bold line is the zero wind line, solid contours are for westerlies, dashed for easterlies. Gray boxes evidence the time period for the SCOUT-O 3 Darwin and SCOUT-AMMA campaigns.

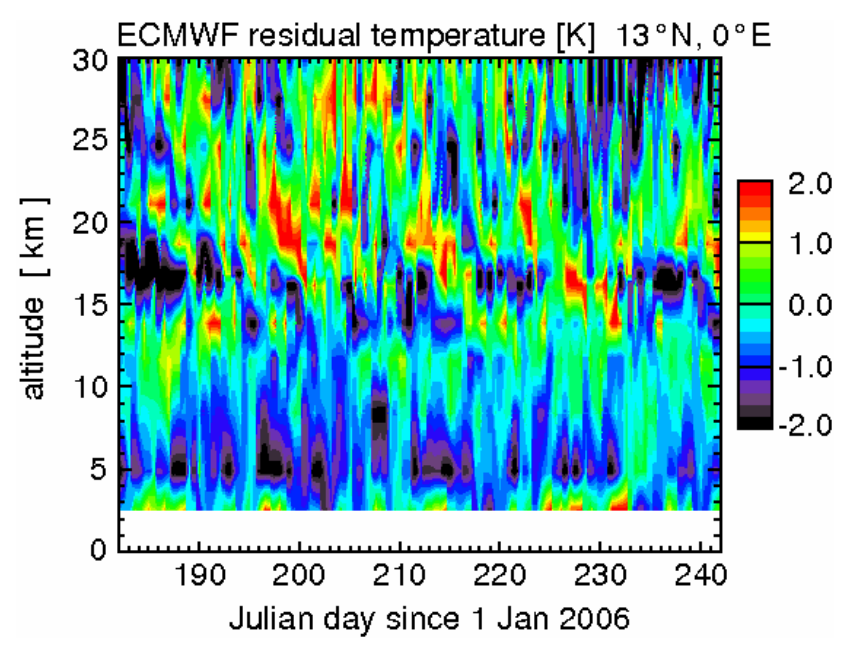

Fig. 7. ECMWF temperature anomaly with respect to the campaign average, at $\left(13^{\circ} \mathrm{N}, 0^{\circ} \mathrm{E}\right)$ for the period $1 \mathrm{July}-30$ August 2006.

Other wave modes are weaker. The amplitude of Kelvin waves is decreasing from early July to August, while that of Rossby waves increases. Equatorial Kelvin waves originating from the Pacific travelling eastwards, sub-equatorial Rossby waves travelling westwards, enhanced MJO activity in the Indian and West Pacific sector, and increased convection in phase with Kelvin waves in June are documented by Janicot et al. (2008). There, a decadal climatology of such planetary wave activity clearly shows how the impact of the Kelvin waves has a seasonal evolution, stronger when the 
ITCZ is closer to the equator, i.e. at the start of the monsoon season, when the interactions between convection and these equatorially-trapped waves are facilitated.

\subsection{Local meteorological conditions}

During the summer 2006, four daily radiosondes, reinforced to eight between 1-15 August, were launched from Niamey by the Direction de la Météorologie Nationale (DMN) of Niger in collaboration with the Atmospheric Radiation Measurements (ARM) Mobile Facility (AMF) (Slingo et al., 2008; Parker et al., 2009).

The mean temperature and zonal and meridional wind speed profiles and their variability (10- and 90-percentiles) over Niamey derived from the 1 July-31 August period are shown in Fig. 9. A similar analysis from the two daily sondes in Ouagadougou has been carried out providing very consistent results, but of coarser temporal resolution and is therefore not shown. On average, the Cold Point Tropopause (CPT) of $195 \mathrm{~K}$ is located at $375 \mathrm{~K}$ potential temperature, $500 \mathrm{~m}$ above the Lapse Rate Tropopause (LRT) at about $16 \mathrm{~km}$. The equilibrium level, the altitude at which the lapse rate starts to increase, is around $14 \mathrm{~km}$. The temperature is most variable in the boundary layer and in the UTLS above the LRT where the amplitude of the deviation reaches $\pm 7 \mathrm{~K}$ at the CPT. With the exception of the monsoon southwesterly flow near the surface, the wind is nearly zonal and easterly at all levels. Evident on the rightmost panels of Fig. 9 are the monsoon south-westerly flow near the surface, the AEJ peaking at $4 \mathrm{~km}$ of $12 \mathrm{~m} / \mathrm{s}$ mean core speed corresponding to a layer of reduced stability, and the TEJ peaking around the tropopause at a speed of $15 \mathrm{~m} / \mathrm{s}$.

The structure and variability of the tropical tropopause layer are greatly affected by wave-like fluctuations, such as gravity waves or Kelvin waves, that influence tropopause height, temperature, high cloud occurrence and altitude, impacting microphysical, dynamic and chemical processes in the TTL (see Fueglistaler et al. (2009) and references therein). We present here an analysis of the temperature fluctuations in the TTL and LS at the time of the campaign. Figure 10 shows the time series of temperature anomaly relative to the campaign mean. Added on the figure are the altitudes of the CPT (white squares) and of the $340 \mathrm{~K}$ and $365 \mathrm{~K}$ isentropic surfaces (black squares). The pronounced wave-fronts in the stratosphere that are descending in time are structures common to the Ouagadougou time-series (not shown) and thus the result of large scale tropical wave activity. Their amplitude of $4 \mathrm{~K}$ is larger than $2 \mathrm{~K}$ derived from ECMWF reanalysis shown in Fig. 7, suggesting that the latter is not fully capturing these waves. This is likely due both to the limited vertical resolution of the underlying ECMWF dynamical model that dampens short vertical scales, and to an additional vertical interpolation of the ECMWF data on a set of pressure levels with $2-3 \mathrm{~km}$ vertical resolution, used in
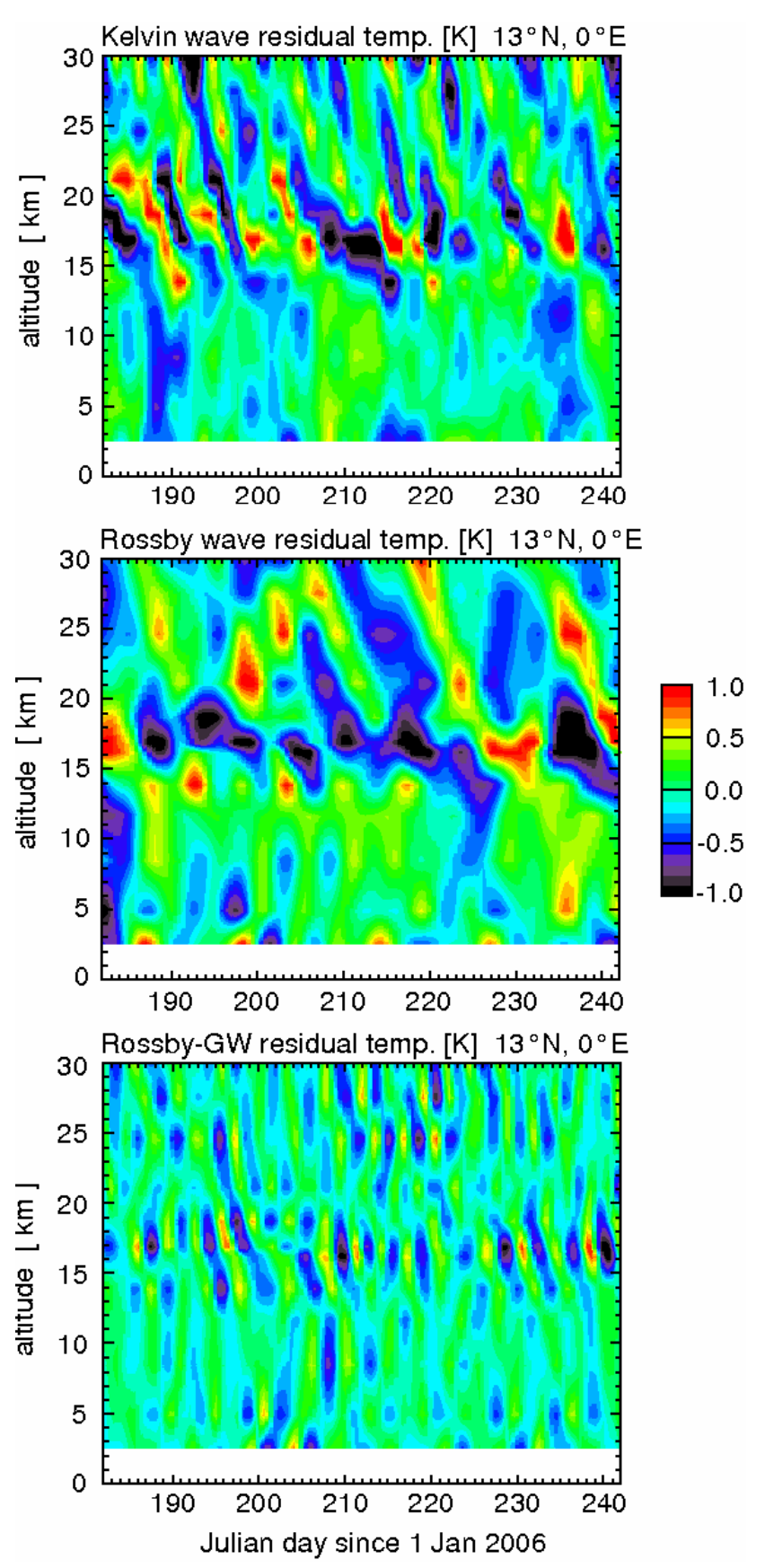

Fig. 8. ECMWF derived residual temperatures from a space-time spectral analysis for $\left(13^{\circ} \mathrm{N}, 0 \mathrm{E}\right)$ with band pass filters for the different equatorial wave modes applied. The results are shown for Kelvin (top panel), equatorial Rossby (middle panel) and Rossbygravity waves (bottom panel).

this analysis, that has further dampened these short vertical scales (Ern et al., 2008).

Figure 11 shows the result of a spectral analysis of the temperature anomaly. The presence of a diurnal cycle is obvious at all levels but of largest amplitude in the surface layer and above the tropopause, then a 3-4 day period in 


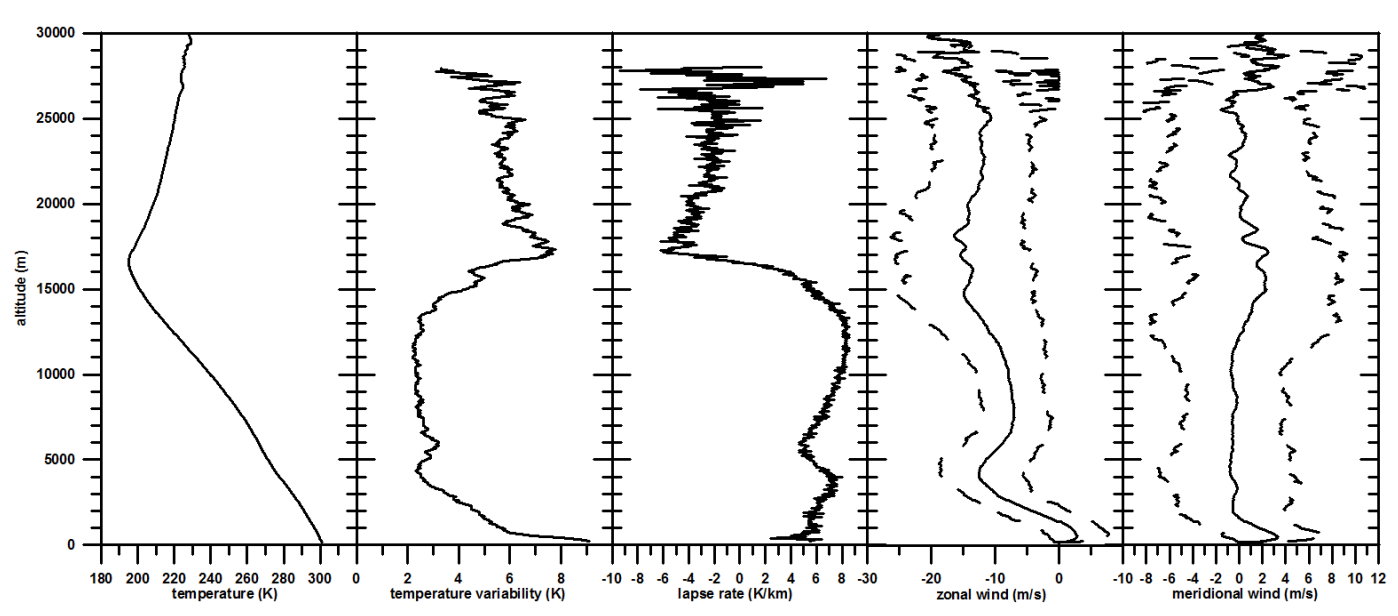

Fig. 9. Mean atmosphere characteristis from the 4 daily radio-sondes of the ARM station in Niamey in July-August 2006. From left to right: mean temperature, 10 to 90 percentiles temperature variability, lapse rate, zonal and meridional wind and 10- and 90-percentiles (dotted lines).

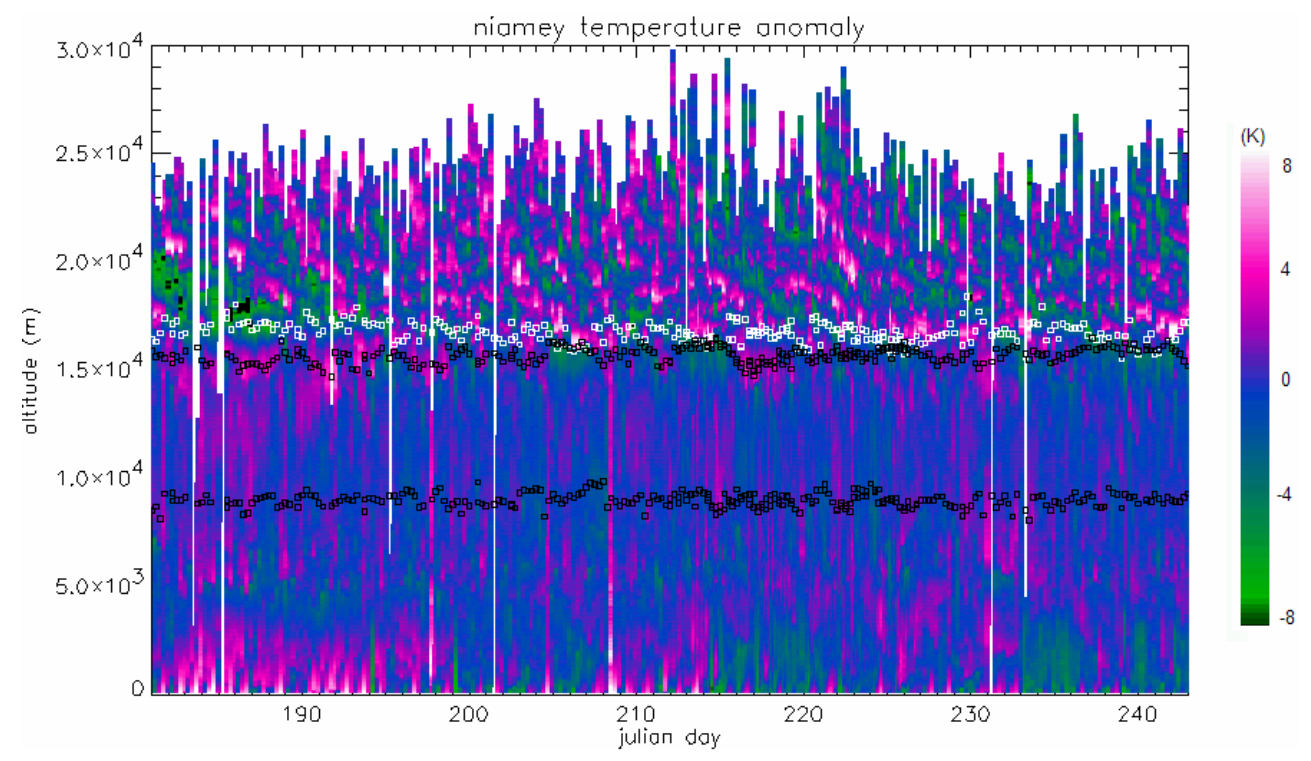

Fig. 10. Time series of atmospheric temperature anomalies in July-August 2006 from the radiosoundings in Niamey. White squares denote the altitude of the Cold Point Tropopause. The two black squared lines represent the $340 \mathrm{~K}$ and $365 \mathrm{~K}$ isentropic levels.

the troposphere, and then longer modulations of 10 days or longer periods associated with Kelvin and Rossby waves.

Figure 12 shows the amplitude and the phase of the average daily change of temperature compared to its noon value at $900,600,150$ and $80 \mathrm{hPa}$. The lower layer near the surface displays an average warming of $5 \mathrm{~K}$ through the day due to the solar heating, combined with advective cooling by the monsoon at night (Parker et al., 2005b). The mid-troposphere $(600 \mathrm{hPa})$ and the equilibrium $(150 \mathrm{hPa})$ levels show only a small warming of less than $1 \mathrm{~K}$ in the afternoon, where the adiabatic cooling of convectively lifted air is compensated by the release of latent heat by precipitation. Most remarkable is the average afternoon cooling at $80 \mathrm{hPa}$, that is $1.5 \mathrm{~km}$ above the CPT, of $2 \mathrm{~K}$ amplitude at sunset compared to the early morning. This diurnal cycle in the lower stratosphere is very similar to that observed by Pommereau and Held (2007) over southern Brazil during the convective season, in coincidence with the diurnal cycle of convective intensity, which was attributed by the authors to the injection of adiabatically cooled air by deep overshooting across the tropopause as proposed by Danielsen (1993) (see (Pommereau and Held, 2007) and Open Discussion therein). A detailed examination of these series of the soundings is outside the scope of this paper, but important here is the confirmation of the existence of a temperature diurnal cycle in the TTL immediately above the tropopause during the convective season above West Africa like that observed over Brazil. 


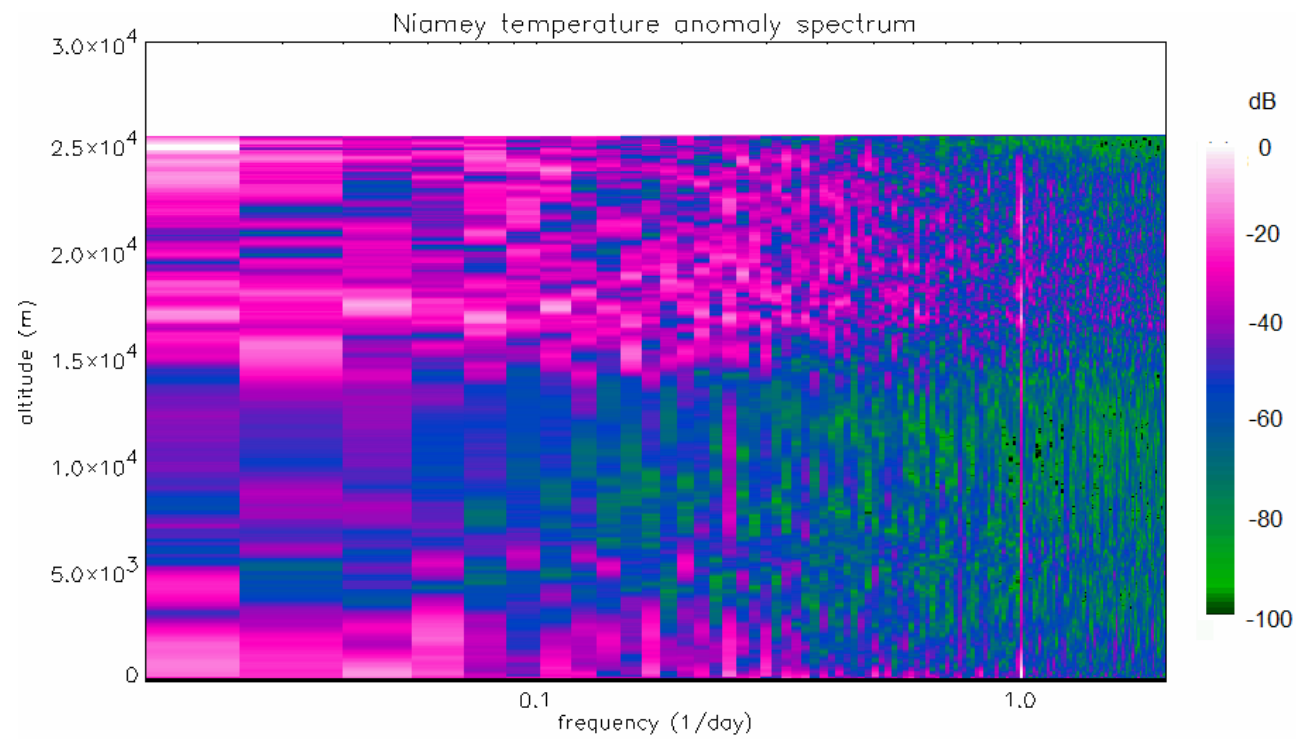

Fig. 11. Power spectrum of temperature anomaly time series.

\section{M55 Geophysica, balloons and sondes payloads}

\subsection{Geophysica payload}

The stratospheric research aircraft M55 Geophysica is described by Stefanutti et al. (1999). The Geophysica was instrumented with a comprehensive payload for in-situ microphysical and chemical measurements as well as spectrometers for remote trace gas measurements.

As some instruments shared the same bay, not all of them could be flown on the same mission. The definition of the optimal payload was decided according to the objectives of the specific flights. Table 1 presents a short description of the instruments and their characteristics.

\subsection{Balloons payload}

The balloons launched from Niamey airport were of two types: $3000-12000 \mathrm{~m}^{3}$ balloons flown for 3-4h, operated by the team of the French Centre National d'Etudes Spatiales (CNES) with the help of the Nigeran Air Force for payload recovery in Burkina Faso, and smaller $1500-4000 \mathrm{~m}^{3}$ plastic balloon sondes operated by the scientists. The instruments available for the balloons were: a micro-DIRAC gas chromatograph for the in situ measurement of halogen species, a micro-SDLA tunable diode laser hygrometer, a SAOZ UVVis spectrometer for remote measurement of ozone, $\mathrm{NO}_{2}$, $\mathrm{H}_{2} \mathrm{O}$ and aerosols extinction, a SAOZ UV version for the remote measurement of $\mathrm{BrO}$, a micro-lidar and a global IR radiometer for cloud detection, a LABS diode laser for aerosols and clouds, an optical particle counter (OPC) for the size distribution of the particles, a NILUCUBE for radiation, lightning optical detectors and finally a HV-AIRS vertical electric field probe. Those available for the sondes were backscatter-

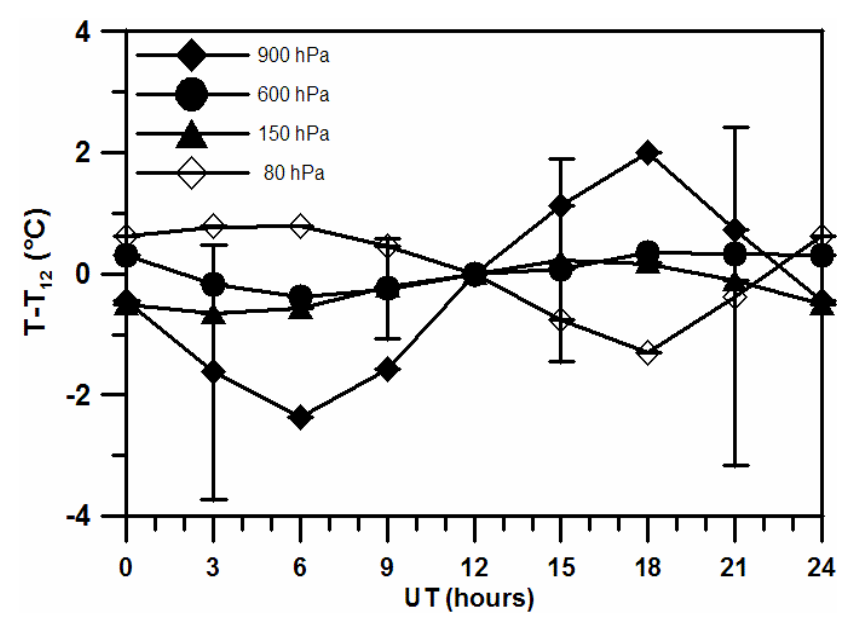

Fig. 12. Average diurnal temperature change at 900, 600, 150 and $80 \mathrm{hPa}$ compared to noontime from the 4 ARM soundings in $\mathrm{Ni}$ amey from 1 July to 31 August, reinforced to 8 per day in 1-15 August.

sonde (BKS) for aerosol and particles, FLASH-B Lyman alpha hygrometers and commercial ozone sensors. Their main characteristics are described in Table 2.

\section{M55 Geophysica, balloons and sondes flights}

The operations were split between Niamey $\left(13.5^{\circ} \mathrm{N}, 2.0^{\circ} \mathrm{E}\right)$ in Niger and Ouagadougou $\left(12.3^{\circ} \mathrm{N}, 1.7^{\circ} \mathrm{W}\right)$ located $400 \mathrm{~km}$ southwest of Niamey in Burkina Faso (see Fig. 2). The SCOUT-O $\mathrm{O}_{3}$ stratospheric balloons and sondes operated from Niamey airport, where three AMMA aircraft, the FAAM 
Table 1. M55 instruments characteristics.

\begin{tabular}{|c|c|c|c|c|c|}
\hline Instrument & Species/Parameters & Measurement Technique & Time resolution & Accuracy/Precision & Reference \\
\hline MAS & $\begin{array}{l}\text { Particle Backscatter Ratio (R) } \\
\text { and Depolarization (D) }\end{array}$ & $\begin{array}{l}\text { Light backscattering } \\
\text { in situ }\end{array}$ & $5 \mathrm{~s}$ & $0.05 / 5 \%$ on $\mathrm{R}, 5 / 10 \%$ on $\mathrm{D}$ & $\begin{array}{l}\text { (Buontempo et al., 2006) } \\
\text { (Cairo et al., 2004) }\end{array}$ \\
\hline FISH & $\mathrm{H}_{2} \mathrm{O}$ (gas and condensed phase) & $\begin{array}{l}\text { Lyman-alpha } \\
\text { in situ }\end{array}$ & $1 \mathrm{~s}$ & $0.15 \mathrm{ppmv} / 6 \%+0.15 \mathrm{ppmv}$ & (Zöger et al., 1999) \\
\hline FLASH-A & $\mathrm{H}_{2} \mathrm{O}$ (gas phase) & $\begin{array}{l}\text { Lyman-alpha } \\
\text { in situ }\end{array}$ & $1 \mathrm{~s}$ & $0.2 \mathrm{ppmv} / 6 \%$ & (Yushkov et al., 1998) \\
\hline FOZAN & $\mathrm{O}_{3}$ & $\begin{array}{l}\text { chemiluminescence } \\
\text { in situ }\end{array}$ & $1 \mathrm{~s}$ & $0.01 \mathrm{ppmv} / 8 \%$ & (Yushkov et al., 1999) \\
\hline HAGAR & $\begin{array}{l}\mathrm{N}_{2} \mathrm{O}, \mathrm{CFC}-12, \mathrm{CFC}-11 \text {, Halon-1211, } \\
\mathrm{H}_{2}, \mathrm{SF}_{6}, \mathrm{CH}_{4}\end{array}$ & gas chromatography & $90 \mathrm{~s}$ & $1-4 \%$ & (Volk et al., 2000) \\
\hline $\mathrm{HAGAR}-\mathrm{CO}_{2}$ & $\mathrm{CO}_{2}$ & $\begin{array}{l}\text { non-dispersive IR abs. } \\
\text { in situ }\end{array}$ & $5 \mathrm{~s}$ & $0.1 \%$ & \\
\hline SIOUX & $\begin{array}{l}\mathrm{NO}, \mathrm{NO}_{\mathrm{y}} \text { (gas phase) } \\
\mathrm{NO}_{\mathrm{y}} \text { (condensed phase) }\end{array}$ & $\begin{array}{l}\text { chemiluminescence } \\
\text { in situ }\end{array}$ & $1 \mathrm{~s}$ & $5 \%-10 \%(\mathrm{NO})$ and $7 \%-15 \%\left(\mathrm{NO}_{\mathrm{y}}\right)$ & $\begin{array}{l}\text { (Schmitt, 2003) } \\
\text { (Voigt et al., 2005) }\end{array}$ \\
\hline ALTO & $\mathrm{CH}_{4}$ & $\begin{array}{l}\text { laser spectrometry } \\
\text { in situ }\end{array}$ & $5 \mathrm{~s}$ & $60 \mathrm{ppbv} / 15 \%$ & (D’Amato et al., 2002) \\
\hline COLD & $\mathrm{CO}$ & $\begin{array}{l}\text { laser spectrometry } \\
\text { in situ }\end{array}$ & $4 \mathrm{~s}$ & $6-9 \% / 3 \mathrm{ppbv}$ & (Viciani et al., 2008) \\
\hline IRIS & $\mathrm{H}_{2} \mathrm{O}$ (isotopes) & $\begin{array}{l}\text { laser spectrometry } \\
\text { in situ }\end{array}$ & $1 \mathrm{~s}$ & $\begin{array}{l}9 \%\left(\delta^{18} \mathrm{O}\right), 20 \%\left(\delta^{17} \mathrm{O}\right), 100 \%\left(\delta^{2} \mathrm{H}\right) \\
\text { at } 100 \mathrm{ppmv}\end{array}$ & (Kerstel et al., 2006) \\
\hline HALOX & $\mathrm{ClO}, \mathrm{BrO}$ & $\begin{array}{l}\text { chemical conversion resonance } \\
\text { fluorescence, in situ }\end{array}$ & $5-30 \mathrm{~min}$. & $\begin{array}{l}20 \% / 2 \mathrm{pptv}(\mathrm{ClO}) \\
35 \% / 2 \mathrm{pptv}(\mathrm{BrO})\end{array}$ & (von Hobe et al., 2005) \\
\hline WAS-1 & $\begin{array}{l}\text { long lived gases } \\
\text { halocarbons (isotopes) }\end{array}$ & $\begin{array}{l}\text { whole air sampler } \\
\text { in situ }\end{array}$ & $5-12 \mathrm{~min}$. & $-1-$ & (Kaiser et al., 2006) \\
\hline WAS-2 & $\mathrm{H}_{2} \mathrm{O}$ (isotopes) & $\begin{array}{l}\text { cryogenic sampler } \\
\text { in situ }\end{array}$ & $30 \mathrm{~min}$. & $-1-$ & (Franz and Röckmann, 2005) \\
\hline MIPAS & $\mathrm{H}_{2} \mathrm{O}, \mathrm{O}_{3}, \mathrm{CH}_{4}, \mathrm{~N}_{2} \mathrm{O}, \mathrm{HNO}_{3}$, and $\mathrm{NO}_{2}$ & $\begin{array}{l}\text { mid-infrared FT spectrometry } \\
\text { remote }\end{array}$ & - & $-1-$ & (Fischer et al., 2008) \\
\hline CRISTA-NF & $\begin{array}{l}\mathrm{H}_{2} \mathrm{O}, \mathrm{O}_{3}, \mathrm{HNO}_{3}, \mathrm{PAN}, \mathrm{CCl}_{4} \\
\text { temperature }\end{array}$ & $\begin{array}{l}\text { mid-infrared spectrometry } \\
\text { remote }\end{array}$ & $1 \mathrm{~min} . /$ profile & $-1-$ & $\begin{array}{l}\text { (Hoffmann et al., 2009) } \\
\text { (Spang et al., 2008) }\end{array}$ \\
\hline COPAS & particles (diam. $>6-10-14 \mathrm{~nm}$ ) & $\begin{array}{l}\text { particle counter } \\
\text { in situ }\end{array}$ & $15-30 \mathrm{~s}$ & $-1-$ & $\begin{array}{l}\text { (Weigel et al., 2009) } \\
\text { (Curtius et al., 2005) }\end{array}$ \\
\hline CIP & particles (diam. $25-1550 \mu \mathrm{m})$ & $\begin{array}{l}\text { particle imager } \\
\text { in situ }\end{array}$ & - & $-1-$ & (DeReus et al., 2009) \\
\hline FSSP-SPP-300, -100 & particles (diam. $0.3-31 \mu \mathrm{m}, 2.7-301 \mu \mathrm{m}$ ) & $\begin{array}{l}\text { particle counter } \\
\text { in situ }\end{array}$ & $2 \mathrm{~s}$ & $20 \% /-$ & (DeReus et al., 2009) \\
\hline TDC & pressure, temperature, horizontal wind & $\begin{array}{l}\text { thermodynamic sensors } \\
\text { in situ }\end{array}$ & $1 \mathrm{~s}$ & $\begin{array}{l}-/ 0.1 \mathrm{~K} \\
-/ 0.1 \mathrm{hPa}\end{array}$ & (Shur et al., 2007) \\
\hline
\end{tabular}

BAe-146, CNRS Falcon F-20 and ATR 42 were also based, while the M55 and the AMMA DLR Falcon-20 were deployed at the air force base 511 of Ouagadougou. Details about the overall AMMA activities can be found in Lebel et al. (2009).

Communication between the two experimental sites was established in order to ensure coordination between activities. Met briefings and decision meetings for collaborative flights were conducted in teleconference between the two sites every morning. The evolution of MCS was monitored by using a Rapid Developing Thunderstorm (RDT) product based on MSG images, developed by Météo-France and available to all (Morel and Senesi, 2002). This product allowed to track the strength and the evolution of the storm every $15 \mathrm{~min}$. Available in Niamey were the four daily radio-sondes of the US Atmospheric Radiation Measurement (ARM) mobile facility in July-August and a C-band radar of the Massachussets Institute of Technology (MIT) (Williams et al., 2009). Two radio-sondes per day were also available in Ouagadougou operated by the Direction de la Météorologie Nationale as well as a C-band radar run by the local Air Force.

Ten stratospheric balloons were flown between 26 July and 25 August from Niamey complemented by 29 heavy sondes carrying several instruments each. The M55 and the DLR Falcon F-20 performed six local flights between 116 August 2006, both aircraft focussing on the sampling of the middle and high troposphere and the stratosphere up to $20 \mathrm{~km}$ altitude, followed by the local C-band radar allowing the mission scientists to monitor and direct in real time the aircraft during their missions. 
Table 2. Balloon instruments characteristics.

\begin{tabular}{|c|c|c|c|c|c|}
\hline Instrument & Species/Parameters & Measurement Technique & Time resolution & Accuracy/Precision & Reference \\
\hline micro-DIRAC & $\begin{array}{l}\mathrm{CFC}-11, \mathrm{CFC}-113, \mathrm{CHCl}_{3} \text {, } \\
\mathrm{CH}_{3} \mathrm{CCl}_{3} \text { and } \mathrm{CCl}_{4}\end{array}$ & $\begin{array}{l}\text { Gas chromatography } \\
\text { in situ }\end{array}$ & $10 \mathrm{~min}$. & $-16.5-15 \%$ & $\begin{array}{l}\text { (Robinson et al., 2000) } \\
\text { (Gostlow et al., 2009) }\end{array}$ \\
\hline micro-SDLA & $\mathrm{H}_{2} \mathrm{O}$ (gas phase), $\mathrm{CH}_{4}, \mathrm{CO}_{2}$ & $\begin{array}{l}\text { laser spectrometry } \\
\text { in situ }\end{array}$ & $1 \mathrm{~s}$ & $-15 \%$ & $\begin{array}{l}\text { (Marecal et al., 2007) } \\
\text { (Durry et al., 2004) }\end{array}$ \\
\hline FLASH-B & $\mathrm{H}_{2} \mathrm{O}$ (gas phase) & $\begin{array}{l}\text { Lyman-alpha } \\
\text { in situ }\end{array}$ & $1 \mathrm{~s}$ & $0.2 \mathrm{ppmv} / 6 \%$ & (Yushkov et al., 1998) \\
\hline SAOZ & $\begin{array}{l}\mathrm{O}_{3}, \mathrm{NO}_{2},\left(\mathrm{H}_{2} \mathrm{O}\right) \text {, cloud extinction } \\
\text { OR BrO }\end{array}$ & $\begin{array}{l}\text { UV-Vis spectrometry } \\
\text { remote }\end{array}$ & $10 \mathrm{~s}$ & $2-15 \%$ & $\begin{array}{l}\text { (Pommereau and Piquard, 1994) } \\
\text { (Pundt et al., 2002) }\end{array}$ \\
\hline micro-LIDAR & Particle Backscatter Ratio (R) & $\begin{array}{l}\text { light backscattering } \\
\text { and depolarization (D), remote }\end{array}$ & $60 \mathrm{~s}$ & $0.05 / 5 \%$ on $\mathrm{R}, 5 / 10 \%$ on $\mathrm{D}$ & (Di Donfrancesco et al., 2006) \\
\hline Global IR & IR radiation & $\begin{array}{l}\text { radiometer } \\
\text { remote }\end{array}$ & $10 \mathrm{~s}$ & $-15 \%-10 \%$ & (Suomi et al., 1958) \\
\hline LABS & $\begin{array}{l}\text { particle Backscatter Ratio (R) } \\
\text { and Depolarization (D) }\end{array}$ & $\begin{array}{l}\text { backscattersonde } \\
\text { in situ }\end{array}$ & $5 \mathrm{~s}$ & $0.05 / 5 \%$ on $\mathrm{R}, 5 / 10 \%$ on $\mathrm{D}$ & $\begin{array}{l}\text { (Buontempo et al., 2006) } \\
\text { (Cairo et al., 2004) }\end{array}$ \\
\hline OPC & $\begin{array}{l}\text { particles }(\mathrm{rad} .0 .15-10.0) \mu \mathrm{m}) \\
\text { condensation nuclei }(\mathrm{rad} . \geq 0.01 \mu \mathrm{m})\end{array}$ & $\begin{array}{l}\text { optical particle counter } \\
\text { in situ }\end{array}$ & $5 \mathrm{~s}$ & $-/ 10 \%$ & (Deshler et al., 2003) \\
\hline NILUCUBE & $\begin{array}{l}\text { UV radiation } \\
\text { profiles }\end{array}$ & $\begin{array}{l}\text { radiometer } \\
\text { remote }\end{array}$ & $1-5 \mathrm{~s}$ & $-1-$ & (Kylling et al., 2003) \\
\hline HV-AIRS & $\mathrm{H}_{2}$ electric field, lightning & $\begin{array}{l}\text { electrostatic sensors } \\
\text { in situ }\end{array}$ & $1 \mathrm{~ms}$ & $-/ \mathrm{DC} 10 \mathrm{mV} / \mathrm{m}$ AC $30 \mu \mathrm{V} / \mathrm{m}$ & - \\
\hline BACKSCATTERSONDE & particle Backscatter Ratio & $\begin{array}{l}\text { light backscattering } \\
\text { in situ }\end{array}$ & $7 \mathrm{~s}$ & $2 \% / 1 \%$ & (Rosen and Kjome, 1991) \\
\hline OZONOSONDE & $\mathrm{O}_{3}$ & $\begin{array}{l}\text { electrochemical cell } \\
\text { in situ }\end{array}$ & $1 \mathrm{~s}$ & $5-10 \% / 2-4 \%$ & (Smit et al., 2007) \\
\hline
\end{tabular}

\subsection{Geophysica flights}

The aircraft was instrumented in Verona, Italy $\left(45.4^{\circ} \mathrm{N}\right.$, $10.9^{\circ} \mathrm{E}$ ) from where it left on the 31 July 2006 for Ouagadougou, arriving on 1 August, after an intermediate stop in Marrakesh, Morocco $\left(31.63^{\circ} \mathrm{N},-8.00^{\circ} \mathrm{E}\right)$; the final part of the last transfer flight is displayed in Fig. 13 panel a, superimposed to a Meteosat IR 10.8 satellite image taken at the time of the flight.

The aircraft performed five scientific local flights from Ouagadougou during the first half of August, then left for the return trip on 16 August (see Fig. 13 panel $g$ for the first part of the return flight), following the same transfer route with intermediate stop in Marrakesh and reached Verona on 17 August. The transfer flights were designed to provide optimal performance for the spectrometers, i.e. at maximum altitude compatible with the route safety.

The local flights were designed according to five different templates, specifically (I) to perform survey flights in conditions as unperturbed as possible by convection, (II) to sample air affected by recent and (III) by aged convection, (IV) to investigate the long range transport across a meridional transect, and finally (V) to validate the satellite borne Cloud-Aerosol LIdar with Orthogonal Polarization (CALIOP) cloud products.

On 4 August 2006 and 13 August 2006, the M55 flew in the TTL region along a north-south transect to cross the latitudinal gradient of the region, under relatively quiescent conditions. This allowed to sample air likely affected by the large scale transport compared to the impact of local convection. The flight tracks for these local flights are shown in Fig. 13, panel b and f. On 4 August, the F-20 Falcon performed similar flights at the same time, following a similar geographical pattern at lower levels.

The influence of MCS on the UTLS was addressed on the flights of 7 August 2006 (see Fig. 13, panel c), when an MCS close-up was attempted, and of 11 August 2006 (see Fig. 13, panel e) when the M55 sampled TTL air that had likely been processed by an MCS system during the previous days, as forecasted by using MSG satellite imagery and foreward trajectory calculations using the LAGRANTO model with a spectral resolution of T319L91. On the 7th, the F-20 Falcon flew at the same time, following a geographical pattern slightly displaced northward with respect to the M55,while on the 11th the F-20 Falcon performed a flight on the same route, sampling the same regions at lower levels.

Finally, on 8 August 2006 (see Fig. 13, panel d), the flight followed the footprint of the CALIOP lidar on board CALIPSO, to validate its cloud products with observations of upper clouds structure and microphysics, including size and shape of ice crystals. High level clouds were observed in proximity of Ouagadougou and, of use for the CALIOP validation, on the last part of the footprint leg.

A list of the payload and data availability for these flights is reported in Table 3. A detailed description of these flights is provided in the supplementary material (http://www.atmos-chem-phys.net/10/2237/ 2010/acp-10-2237-2010-supplement.pdf). 
Table 3. M55 flights, aims, instruments and data availability.

\begin{tabular}{|c|c|c|c|c|c|c|c|c|c|}
\hline Date & 31 July & 1 August & 4 August & 7 August & 8 August & 11 August & 13 August & 16 August & 17 August \\
\hline Objective & UTLS profile & UTLS profile & UTLS profile & UTLS profile & MSC close-up & CALIOP val & MCS aged outflow & UTLS profile & UTLS profile \\
\hline \multicolumn{10}{|c|}{ In situ tracers, $\mathrm{H}_{2} \mathrm{O}$} \\
\hline FISH & $\mathrm{Ok}$ & No data & Ok & $\mathrm{Ok}$ & $\mathrm{Ok}$ & $\mathrm{Ok}$ & Ok & $\mathrm{Ok}$ & Ok \\
\hline FLASH & Not present & Not present & Ok & $\mathrm{Ok}$ & Ok & $\mathrm{Ok}$ & No data & Not present & Not present \\
\hline FOZAN & Not present & Not present & Ok & $\mathrm{Ok}$ & $\mathrm{Ok}$ & $\mathrm{Ok}$ & Ok & Ok & Ok \\
\hline SIOUX & No data & No data & No data & $\mathrm{Ok}$ & Ok & No data & $\mathrm{Ok}$ & Ok & Ok \\
\hline HAGAR & $\mathrm{Ok}$ & Ok & Ok & no data & Ok & Ok & Ok & $\mathrm{Ok}$ & Ok \\
\hline ALTO & Ok & No data & Ok & $\mathrm{Ok}$ & Ok & No data & No data & Ok & Ok \\
\hline COLD & $\mathrm{Ok}$ & Not present & No data & $\mathrm{Ok}$ & Ok & No data & Not present & Not present & Not present \\
\hline IRIS & Not present & Not present & Not present & $\mathrm{Ok}$ & Not present & Not present & $\mathrm{Ok}$ & $\mathrm{Ok}$ & Not present \\
\hline HALOX & No data & No data & $\mathrm{Ok}$ & Ok & Ok & $\mathrm{Ok}$ & Ok & $\mathrm{Ok}$ & Ok \\
\hline WAS & No data & No data & $\mathrm{Ok}$ & $\mathrm{Ok}$ & Ok & $\mathrm{Ok}$ & Ok & Not present & Not present \\
\hline \multicolumn{10}{|c|}{ Remote Sensors } \\
\hline MIPAS & Ok & Ok & Ok & $\mathrm{Ok}$ & $\mathrm{Ok}$ & $\mathrm{Ok}$ & Ok & Ok & Ok \\
\hline CRISTA-NF & Ok & Ok & Ok & Ok & Ok & Ok & Ok & Ok & Ok \\
\hline Particles & & & & & & & & & (in situ) \\
\hline COPAS_1 & $\mathrm{Ok}$ & Ok & $\mathrm{Ok}$ & Not present & $\mathrm{Ok}$ & Ok & Ok & Ok & Ok \\
\hline COPAS_2 & $\mathrm{Ok}$ & No data & $\mathrm{Ok}$ & $\mathrm{Ok}$ & Ok & Ok & Ok & Ok & Not present \\
\hline CIP & Not present & Not present & Not present & $\mathrm{Ok}$ & Ok & Ok & Ok & $\mathrm{Ok}$ & Ok \\
\hline FSSP 100 & Ok & Ok & $\mathrm{Ok}$ & $\mathrm{Ok}$ & $\mathrm{Ok}$ & $\mathrm{Ok}$ & Ok & $\mathrm{Ok}$ & Ok \\
\hline FSSP 300 & No data & No data & Not present & Not present & Not present & Not present & Not present & Not present & Not present \\
\hline MAS & Ok & Ok & Ok & Ok & Ok & Ok & Ok & Ok & $\mathrm{Ok}$ \\
\hline \multicolumn{10}{|l|}{ Meteorology } \\
\hline UCSE & $\mathrm{Ok}$ & Ok & $\mathrm{Ok}$ & $\mathrm{Ok}$ & $\mathrm{Ok}$ & $\mathrm{Ok}$ & Ok & Ok & Ok \\
\hline TDC & $\mathrm{Ok}$ & Not present & $\mathrm{Ok}$ & $\mathrm{Ok}$ & Ok & Ok & Ok & Ok & Ok \\
\hline
\end{tabular}

\subsection{Balloons and sondes flights}

The concept of the campaign was to associate several payloads of compatible operational requirements below the same balloon for complementary measurements oriented toward a specific scientific objective. Because of the limited reliability of model predictions, flight decisions were made on now-casting from the information available from the AMMA Rapid Thunderstorm Development (RDT) product refreshed every $15 \mathrm{~min}$ and those of the MIT C-Band radar available every $10 \mathrm{~min}$. When possible, the balloons were accompanied by a sonde as close as possible, but not before sunset because of the stray-light restriction of the BKS and FLASH hygrometer.

Four balloon templates were designed: Ice and Aerosols, Water Vapour, Anvils and Cirrus, and Chemistry.

Ice and Aerosols focussed on the description of cirrus optical properties, microphysics, and transport from the PBL to the UTLS if possible in an outflow region. The payload included OPC, LABS and micro-DIRAC. The plan was to reach $22-23 \mathrm{~km}$, dwell there at constant level for one hour and then descend slowly into the TTL for another $1-2 \mathrm{~h}$. Two flights of this type have been made, on 31 July and $17 \mathrm{Au}$ gust. An additional flight carrying the OPC alone was performed on 31 July.

Water Vapour aimed at studying troposphere to stratosphere transport triggered by overshooting deep convection with in situ measurements of water vapour, ice clouds and tracers in the lower stratosphere, if possible close to an MCS or local convection. The flight train was formed of microSDLA, LABS and micro-DIRAC. The flight template foresaw a ceiling at about $25 \mathrm{~km}$ with a short float followed by a slow descent through the lower stratosphere and the TTL. Two flights of this type were completed on 5 and 23 August.

Anvil and Cirrus was intended to sample cloud tops and turrets and document the possible impact of lightning and convective overshoot. The payload was made of remote sensing instruments: the micro-LIDAR, SAOZ- $\mathrm{H}_{2} \mathrm{O}$, IRradiometer, HV-AIRS and lightning optical detectors. The objective was to fly directly next or above thunderstorms, at about $22 \mathrm{~km}$ and then to descent very slowly accross the tropopause. A successful flight in the vicinity of a storm area was achieved on 7 August.

Finally, Chemistry was to study $\mathrm{NO}_{\mathrm{x}}$ production by lightning, bromine chemistry $\left(\mathrm{CH}_{3} \mathrm{Br}\right.$ and $\left.\mathrm{BrO}\right)$ and radiation. The payload associated a SAOZ, a SAOZ-BrO, microDIRAC and NILUCUBE. The plan was to fly in the afternoon downwind of a MCS for daytime in situ measurements during ascent up to $28-30 \mathrm{~km}$ followed by remote westward cloud free observations at sunset from float altitude. Two flights were carried out, on 10 and 19 August.

The average duration of the flights was of $3-4 \mathrm{~h}$ with landings $100-200 \mathrm{~km}$ west of Niamey. Payloads were recovered typically after 2-3 days, often delayed by flooding in the region, and their refurbishment required 2 to 3 more days. The list of the balloon payloads and data availability for these flights is provided in Table 4. Each flight track is shown in Fig. 14 superimposed to MSG $10.8 \mu \mathrm{m}$ brightness 

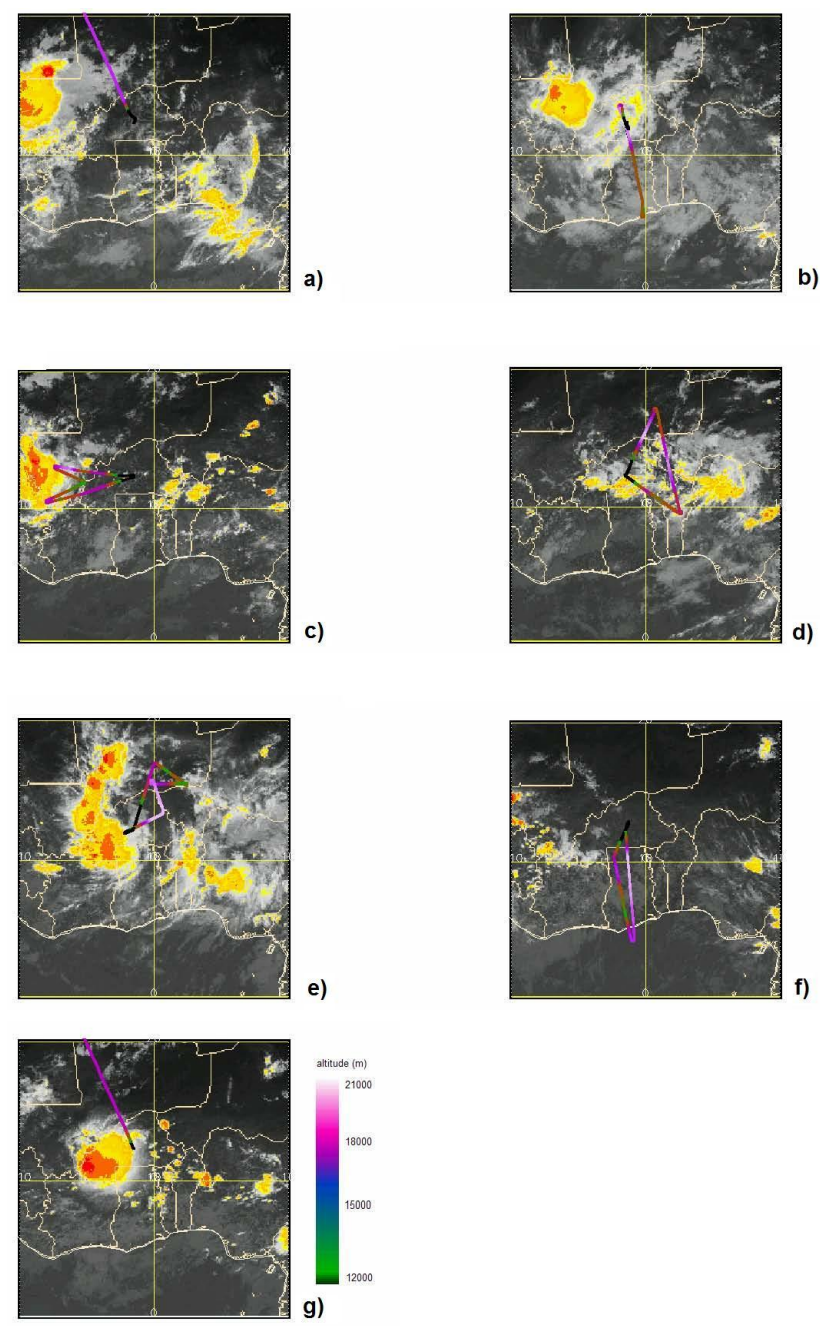

Fig. 13. M55 flight tracks superimposed to Meteosat IR $10.8 \mu \mathrm{m}$ satellite images. Colours along the flight tracks code the altitude. Images refer to the mid-time of the aircraft flight, panels from a to $\mathrm{g}$ are respectively from left to right and from top to bottom: $1 \mathrm{Au}-$ gust at 13:00, 4 August at 10:00, 7 August at 14:00, 8 August at 13:30, 11 August at 16:30, 13 August at 14:30, 16 August at 15:00 (times are UTC). Colours on the images code the cloud brightness temperature, orange is colder than $-65^{\circ} \mathrm{C}$.

temperature images. High cloud tops $\left(T<65^{\circ} \mathrm{C}\right)$, which are a proxy for convective activity, are coded in orange.

Twenty-nine sondes were flown between 26 July and 25 August all carrying a Vaisala RS92 PTU and an ozone sensor, 9 of them a BKS sonde, and 6 both a BKS and a FLASH hygrometer. When possible the BKS or BKS/FLASH flights were conducted in conjunction with the balloon flights described above. The list of soundings is given in Table 5. A brief report of balloon and sonde flights carried out each day is provided in the supplementary material (http://www.atmos-chem-phys.net/10/ 2237/2010/acp-10-2237-2010-supplement.pdf).
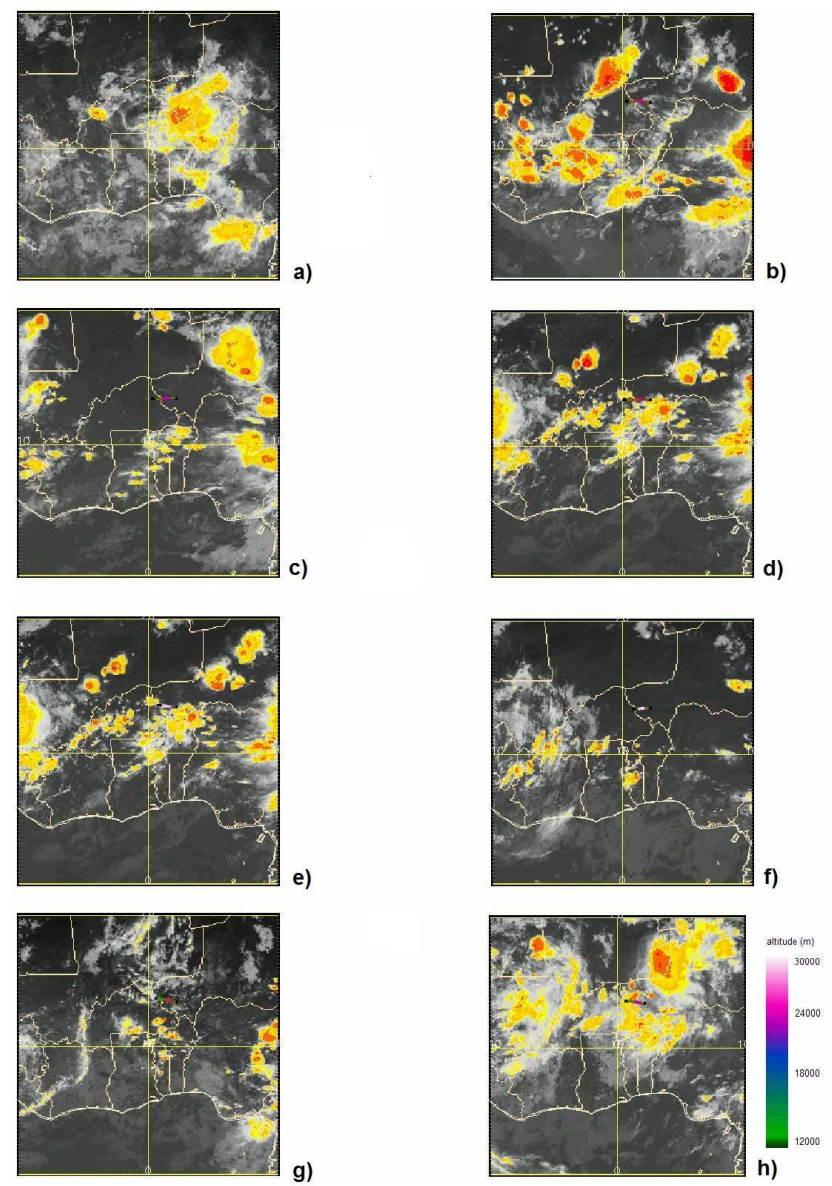

Fig. 14. Balloon flight tracks superimposed on MSG IR $10.8 \mu \mathrm{m}$ brightness temperature images. (a) 31 July at 10:00, (b) 31 July at 19:30, (c) 5 August at 20:30, (d) 7 August at 18:30, (e) 10 August at 18:00, (f) 17 August at 13:30, (g) 19 August at 18:00, (h) 23 August at 20:00 (time in UTC). Colours along the flight tracks codes the altitude. Colours on the image code the cloud brightness temperature, orange is colder than $-65^{\circ} \mathrm{C}$. On the first figure, the balloon flight track is not present due to lack of geolocation of the payload.

\subsection{Ozonesondes}

Almost daily ozonesondes were performed between 26 July and 25 August, some of them combined with the flights described previously. These ozone profiles are displayed in Fig. 15: they show steady increasing values from $0.03 \mathrm{ppmv}$ at the surface to $0.1 \mathrm{ppmv}$ around $15 \mathrm{~km}$ a little below the $\mathrm{CPT}$. Above $15 \mathrm{~km}$ the ozone mixing ratios increase rapidly throughout the TTL. The profiles show remarkably small day to day changes except in the planetary boundary layer and in the upper troposphere where lower ozone was observed on 14 August and higher on 2 and 23 August. 
Table 4. Balloon flights, aims, instruments and data availability.

\begin{tabular}{|c|c|c|c|c|c|c|c|c|}
\hline Date & 31 July & 31 July & 5 August & 7 August & 10 August & 17 August & 19 August & 23 August \\
\hline Objective & Aerosol & Ice and Aerosols 1 & Water Vapour 1 & Anvil and Cirrus 1 & Chemistry 1 & Ice and Aerosols 2 & Chemistry 2 & Water Vapour 2 \\
\hline \multicolumn{9}{|l|}{ In situ tracers, $\mathrm{H}_{2} \mathrm{O}$} \\
\hline u-SDLA & Not present & Not present & Ok & Not present & Not present & Not present & Not present & Ok \\
\hline u-Dirac & Not present & No data & No data & Not present & Ok & Ok & No data & Ok \\
\hline \multicolumn{9}{|l|}{ Remote Sensors } \\
\hline SAOZ & Not present & Not present & Not present & Ok & Ok & Not present & Ok & Not present \\
\hline IR-rad & Not present & Not present & Not present & Ok & Not present & Not present & Not present & Not present \\
\hline u-LIDAR & Not present & Not present & Not present & Ok & Not present & Not present & Not present & Not present \\
\hline HV-AIRS & Not present & Not present & Not present & Ok & Not present & Not present & Not present & Not present \\
\hline NILUcube & Not present & Not present & Not present & Not present & $\mathrm{Ok}$ & Not present & No data & Not present \\
\hline \multicolumn{9}{|l|}{ Particles (in situ) } \\
\hline $\mathrm{OPC}, \mathrm{CN}, \mathrm{O}_{3}$ & Ok & No data & Not present & Not present & Not present & $\mathrm{Ok}$ & Not present & Not present \\
\hline LABS & Not present & Ok & $\mathrm{Ok}$ & Not present & Not present & Ok & Not present & Ok \\
\hline \multicolumn{9}{|l|}{ Meteorology } \\
\hline Temperature, pressure & Ok & Ok & Ok & Ok & $\mathrm{Ok}$ & $\mathrm{Ok}$ & Ok & Ok \\
\hline
\end{tabular}

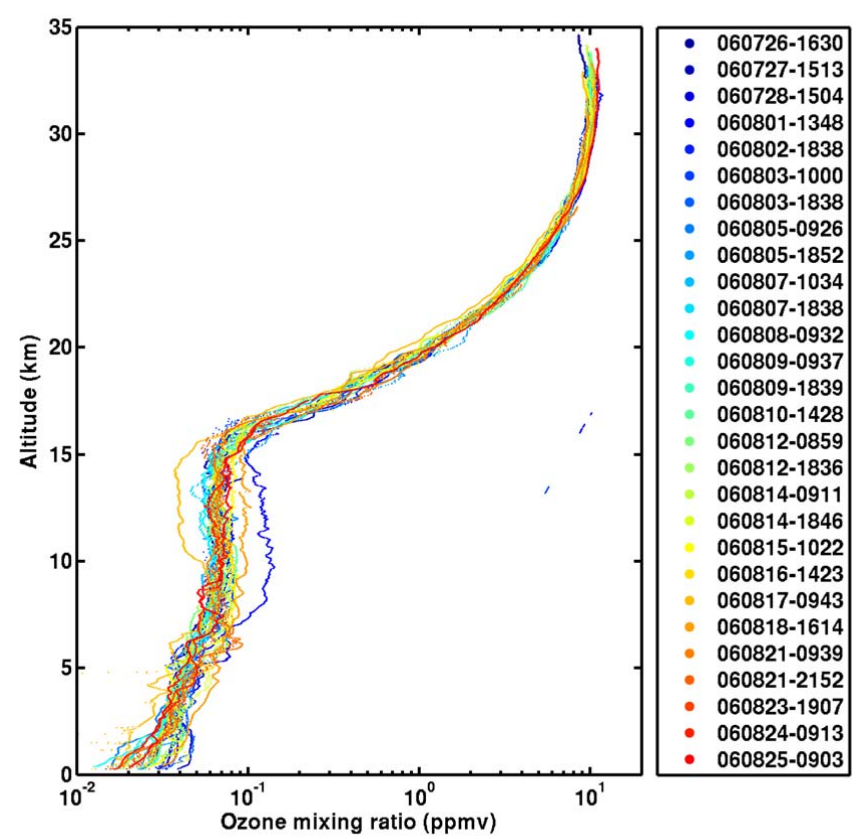

Fig. 15. The vertical profiles of ozone mixing ratio from 28 ozone soundings from Niamey between 26 July and 25 August 2006.

\section{Conclusions}

A tropical stratospheric aircraft, balloons and sondes campaign has been successfully conducted in West Africa during the peak of the 2006 monsoon season in the framework of the observational activities of the EU funded projects AMMA and $\mathrm{SCOUT}_{-} \mathrm{O}_{3}$. The campaign aimed at: studying the effects of deep convection on trace gases, aerosols and water vapour distributions; characterizing the chemical composition and the transport mechanisms in the UTLS over West Africa; and validating the CALIOP products in terms of observed aerosol and cirrus properties.
The data collected during the campaign produced a large amount of observations on the impact of deep convective systems and large-scale transport on the lower stratosphere. Among most interesting results, aside from the observation of a large impact of convection and surface heating on the thermal structure of the lower stratosphere shown by the diurnal cycle of temperature, are the water observations in the TTL and in the lower stratosphere. On average, water vapour measurements present the typical profile of the Northern Hemisphere summer: a relatively wet $(6 \mathrm{ppmv})$ cold point with a slowly decreasing mixing ratio above, to approximately $4.2-4.5 \mathrm{ppmv}$ at the hygropause at about $19-20 \mathrm{~km}$ (68-58 hPa, 440-470 K) (Khaykin et al., 2009; Schiller et al., 2009).

The balloon profiles over Niamey and those of the M-55 Geophysica further west are very consistent, both in qualitative and quantitative terms. Below the cold point, the bulk of convective outflow strongly moistens the TTL and the observations of high specific humidity are frequently accompanied by high relative humidity, sometimes supersaturation, and cloud particles. Above the cold point, a noticeable difference between our measurements and the lowvertical-resolution, smooth, satellite observations reported previously, is the presence of highly structured layers of enhanced water vapour. Though observed in sub-saturated air, few observations also show particles at the same levels. Water vapour layers have been observed either close to deep convective events or could be traced by back trajectory calculations to regions with likely overshoots into the stratosphere (Khaykin et al., 2009). These observations in particular those reported several hours downwind a MCS, are clear indication that deep convection has the potential to moisten the TTL above the cold point irreversibly, as also shown by the SCOUT-O ${ }_{3}$ M-55 measurements in Darwin (Corti et al., 2008). Injection of tropospheric air in the layers of enhanced 
Table 5. Sonde flight dates and times, instruments and data availability.

\begin{tabular}{|c|c|c|c|c|}
\hline Date, Time & Ozone & PTU & Backscattersonde & FLASH-B \\
\hline 26 July 2006 16:31 & $\mathrm{Ok}$ & Ok & Not present & Not present \\
\hline 27 July 2006 15:13 & $\mathrm{Ok}$ & Ok & Not present & Not present \\
\hline 28 July 2006 15:04 & $\mathrm{Ok}$ & Ok & Not present & Not present \\
\hline 1 August 2006 13:49 & $\mathrm{Ok}$ & Ok & Not present & Not present \\
\hline 2 August 2006 18:40 & $\mathrm{Ok}$ & Ok & $\mathrm{Ok}$ & Not present \\
\hline 3 August 2006 10:00 & $\mathrm{Ok}$ & Ok & Not present & Not present \\
\hline 3 August 2006 18:38 & $\mathrm{Ok}$ & Ok & $\mathrm{Ok}$ & $\mathrm{Ok}$ \\
\hline 5 August 2006 09:26 & Ok & $\mathrm{Ok}$ & Not present & Not present \\
\hline 5 August 2006 18:52 & Ok & Ok & Ok & Ok \\
\hline 7 August 2006 10:34 & $\mathrm{Ok}$ & Ok & Not present & Not present \\
\hline 7 August 2006 18:38 & $\mathrm{Ok}$ & Ok & $\mathrm{Ok}$ & $\mathrm{Ok}$ \\
\hline 8 August 2006 09:32 & $\mathrm{Ok}$ & Ok & Not present & Not present \\
\hline 9 August 2006 09:37 & $\mathrm{Ok}$ & Ok & Not present & Not present \\
\hline 9 August 2006 18:39 & $\mathrm{Ok}$ & Ok & $\mathrm{Ok}$ & Not present \\
\hline 10 August 2006 14:28 & $\mathrm{Ok}$ & Ok & Not present & Not present \\
\hline 12 August 2006 08:59 & $\mathrm{Ok}$ & $\mathrm{Ok}$ & Not present & Not present \\
\hline 12 August 2006 18:38 & $\mathrm{Ok}$ & Ok & $\mathrm{Ok}$ & Not present \\
\hline 14 August 2006 09:11 & $\mathrm{Ok}$ & $\mathrm{Ok}$ & Not present & Not present \\
\hline 14 August 2006 18:46 & $\mathrm{Ok}$ & Ok & $\mathrm{Ok}$ & Ok \\
\hline 15 August 2006 10:22 & Ok & Ok & Not present & Not present \\
\hline 16 August 2006 14:23 & Ok & Ok & Not present & Not present \\
\hline 17 August 2006 09:43 & $\mathrm{Ok}$ & Ok & Not present & Not present \\
\hline 18 August 2006 16:14 & $\mathrm{Ok}$ & Ok & Not present & Not present \\
\hline 19 August 2006 15:27 & Ok & Ok & Not present & Not present \\
\hline 21 August 2006 09:39 & Ok & Ok & Not present & Not present \\
\hline 21 August 2006 21:52 & $\mathrm{Ok}$ & Ok & Ok & Ok \\
\hline 23 August 2006 19:07 & $\mathrm{Ok}$ & Ok & Ok & Ok \\
\hline 24 August 2006 09:13 & $\mathrm{Ok}$ & Ok & Not present & Not present \\
\hline 25 August 2006 09:03 & Ok & Ok & Not present & Not present \\
\hline
\end{tabular}

water vapour is apparent also in the coincident ozone profile measured on the same balloon (Khaykin et al., 2009). However, the importance of the contribution of these local events to the stratospheric water budget on a global scale still needs to be understood.

A very new observation provided by the HV-AIRS probe is the electrical field in the UTLS, whose effects on the ice crystals injected in the stratosphere are currently under further examination (J. J. Berthelier, personal communication, 2009). The average level of main convective outflow was located between 350 and $360 \mathrm{~K}$ (one day reaching $370 \mathrm{~K}$ ) (Homan et al., 2009). The IRIS water isotope profiles of 7 August show slight deviations from Rayleigh-like gradual depletion between 330 and $370 \mathrm{~K}$, that is possibly indication of convective ice-lofting to altitudes below the cold point (Iannone et al., 2009). In general, there is less compelling evidence of irreversible mixing after overshooting of convective air from tracer measurement than from water measurements. The fact that overshooting has no large impact on vertical profile of tracers (Homan et al., 2009) has been at- tributed to the different sensitivities of tracer and water substances profiles to vertical mixing, water being the most sensitive while long lived tracers are less sensitive. Moreover it has to be stressed that no fresh convection appears to have been measured by the M55, so that tracer measurements from the Geophysica may not have picked up the signal of fresh convective injection.

Stratospheric trace gas correlations and profiles showed that the observed region was mainly outside the so-called isolated tropical pipe (Plumb, 1996) - only the last M55 flight toward the equator was able to reach into it. Air mixing in from the extratropical stratosphere became discernible in the LS while no evidence was found for isentropic in-mixing from the extratropical stratosphere in the TTL below the tropical tropopause (Homan et al., 2009). Cross-hemispheric tropical transport in the middle and upper troposphere was also reported (Real et al., 2009).

In general, the African TTL in August appeared to be wetter and warmer than that observed in November in Darwin, with much higher $\mathrm{CN}$ and $\mathrm{O}_{3}$ in the lower stratosphere. 
Backtrajectory and RDF analysis suggests that the African lower stratosphere was influenced by an influx from northeast Asia, probably in connection with Asian monsoon anticyclone activity (Schiller et al., 2009).

A permanent particle layer between $19-20 \mathrm{~km}$ was detected by balloon, sondes and aircraft of small $\left(30 \mathrm{~cm}^{3}\right.$ $\leq 0.15 \mu \mathrm{m}$ OPC, $40 \mathrm{~cm}^{3}$ COPAS), not depolarizing and thus liquid (LABS) particles, shown by CALIPSO to be present at all longitudes between $10^{\circ} \mathrm{S}-20^{\circ} \mathrm{N}$ (Vernier et al., 2009). This aerosol layer was identified as the sulfate particles plume resulting from the eruption of the $\mathrm{La}$ Soufriere Hills volcano in Monserrat Island in the Caribbean on 20 May 2006, whose $\mathrm{SO}_{2}$ cloud was also observed during one week after the eruption by the AURA-OMI satellite (Carn et al., 2007; Prata et al., 2007). Particle number density measurements showed a large variability in the troposphere, with events of fresh particle nucleation frequently observed, likely due to MCS activity providing favourable conditions for particle formation. The stratospheric number density profile was compact below the volcanic plume in the lower stratosphere, with the total particle number and its non-volatile fraction respectively increasing and decreasing upward (Borrmann et al., 2009).

Finally, large reactive nitrogen $\left(\mathrm{NO}_{\mathrm{y}}\right)$ containing particles were observed near and below the tropical tropopause on 8 August 2006 by instruments onboard the M55-Geophysica. The particles, most likely NAT, had dilute concentrations below $10^{-4} \mathrm{~cm}^{-3}$ and diameters less than $6 \mu \mathrm{m}$. The NAT particle layer extended between 15.1 and $17.5 \mathrm{~km}$ over large areas. Satellite observations suggest that the NAT particles could have nucleated on ice fed by convective activity. The in-situ detection of NAT particles combined with global model simulations indicate the potential for a tropical tropopause NAT particle belt (Voigt et al., 2008).

These valuable observations contribute to build a global picture of the tropical LS and TTL and are of even more value since they came from Sahelian Africa, a region heavily under sampled.

This paper provides the general overview of the campaign in terms of observational activities and meteorological context and illustrates the main highlights of the experimental results. More informations on the measurements and their analysis will be found in the papers part of this special issue.

Acknowledgements. The balloon campaign was supported by the EC Integrated Project SCOUT-O 3 (505390-GOCE-CT-2004).

The M55-Geophysica campaign was supported by the EEIGGeophysica Consortium, CNRS-INSU, EC Integrated Projects AMMA-EU (Contract Number 004089-2), SCOUT-O 3 and CNES.

The deployment of IRIS and WAS was partially supported by the European Fleet for Airborne Research project (EUFAR) (EC-FP6 Contract Number 506514).

The OPC measurements were partly funded by the US National Science Foundation.
The DLR Falcon F-20 campaign was funded through AMMA-EU and DLR.

The radiosoundings in Niamey were funded by AMMA-EU and the ARM program (US DoE).

We would like to thank all the scientists, aircraft operators as well as local scientists and representatives in Burkina Faso for their help and support during the planning and execution of the Ouagadougou campaign. Stefano Balestri and Ana Alfaro Martinez (ERS) are gratefully acknowledged for their operations in Verona and Ouagadougou. Kare Edvardsen and Tron Danielsen (NILU), Sergey Kaikhin (CAO, Russia) and Pierre Francois (Service d'Aeronomie) assisted in the preparation and operation of the NILU-CUBE.

We also acknowledge support from the AMMA Operations Centre in Niamey, Niger.

Based on a French initiative, AMMA was built by an international scientific group and is currently funded by a large number of agencies, especially from France, the United Kingdom, the United States, and Africa. It has been a beneficiary of a major financial contribution from the European Community Sixth Framework Programme (AMMA-EU). Detailed information on scientific coordination and funding is available on the AMMA International website at http://www.amma-international.org.

Edited by: D. Brunner

\section{References}

Alcala, C. M. and Dessler, A. E.: Observations of deep convection in the tropics using the Tropical Rainfall Measuring Mission (TRMM) precipitation radar, J. Geophys. Res., 107, AAC-171-4, doi:10.1029/2002/D002457, 2002.

Borrmann, S., Luo, B., and Mishchenko, M.: The application of the T-matrix method to the measurement of aspherical particles with forward scattering optical particle counters, J. Aerosol Sci., 31, 789-799, 2000.

Borrmann, S., Kunkel, D., Weigel, R., Minikin, A., Deshler, T., Wilson, J. C., Curtius, J., Shur, G. N., Belyaev, G. V., Law, K. S., and Cairo, F.: Aerosols in the tropical and subtropical UT/LS: insitu measurements of submicron particle abundance and volatility, Atmos. Chem. Phys. Discuss., 9, 24587-24628, 2009, http://www.atmos-chem-phys-discuss.net/9/24587/2009/.

Brunner, D., Siegmund, P., May, P. T., Chappel, L., Schiller, C., Mller, R., Peter, T., Fueglistaler, S., MacKenzie, A. R., Fix, A., Schlager, H., Allen, G., Fjaeraa, A. M., Streibel, M., and Harris, N. R. P.: The SCOUT-O3 Darwin Aircraft Campaign: rationale and meteorology, Atmos. Chem. Phys., 9, 93-117, 2009, http://www.atmos-chem-phys.net/9/93/2009/.

Buontempo, C., Cairo, F., Di Donfrancesco, G., Morbidini, R., Viterbini, M., and Adriani, A. : Optical measurements of atmospheic particles from airborne platform: in-situ and remote sensing instruments for balloons and aircrafts, Ann. Geophys.-Italy, 49, 57-64, 2006.

Cairo, F., Adriani, A., Viterbini, M., Di Donfrancesco, G., Mitev, V., Matthey, R., Bastiano, M., Redaelli, G., Dragani, R., Ferretti, R., Rizi, V., Paolucci, T., Bernardini, L., Cacciani, M., Pace, G., and Fiocco, G.: Polar stratospheric clouds observed during the Airborne Polar Experiment-Geophysica Aircraft in Antarc- 
tica (APE-GAIA) campaign, J. Geophys. Res., 109, D07204, doi:10.1029/2003JD003930, 2004.

Carn, S. A., Krotkov, N. A., Yang, K., Hoff, R. M., Prata, A. J., Krueger, A. J., Loughlin, S. C., and Levelt, P. F.: Extended observations of volcanic $\mathrm{SO}_{2}$ and sulfate aerosol in the stratosphere, Atmos. Chem. Phys. Discuss., 7, 2857-2871, 2007, http://www.atmos-chem-phys-discuss.net/7/2857/2007/.

Chaboureau, J.-P., Cammas, J.-P., Duron, J., Mascart, P. J., Sitnikov, N. M., and Voessing, H.-J.: A numerical study of tropical crosstropopause transport by convective overshoots, Atmos. Chem. Phys., 7, 1731-1740, 2007,

http://www.atmos-chem-phys.net/7/1731/2007/.

Corti, T., Luo, B. P., Peter, P., Vömel, H., and Fu, Q.: Mean radiative energy balance and vertical mass fluxes in the equatorial upper troposphere and lower stratosphere, Geophys. Res. Lett., 32, L06802, doi:10.1029/2004GL021889, 2005.

Corti, T., Luo, B. P., de Reus, M., Brunner, D., Cairo, F., Mahoney, M. J., Martucci, G., Matthey, R., Mitev, V., dos Santos, F. H., Schiller, C., Shur, G., Sitnikov, N. M., Spelten, N., Vossing, H. J., Borrmann, S., and Peter, T.: Unprecedented evidence for overshooting convection hydrating the tropical stratosphere, Geophys. Res. Lett., 35, L10810, doi:10.1029/2008GL033641, 2008.

Curtius, J., Weigel, R., Vssing, H.-J., Wernli, H., Werner, A., Volk, C.-M., Konopka, P., Krebsbach, M., Schiller, C., Roiger, A., Schlager, H., Dreiling, V., and Borrmann, S.: Observations of meteoric material and implications for aerosol nucleation in the winter Arctic lower stratosphere derived from in situ particle measurements, Atmos. Chem. Phys., 5, 3053-3069, 2005, http://www.atmos-chem-phys.net/5/3053/2005/.

D’Amato, F., Mazzinghi, P., and Castagnoli, F: Methane analyzer based on TDL's for measurements in the lower stratosphere: design and laboratory tests, Appl. Phys., B75, 195-202, 2002.

Danielsen, E. F.: A dehydration mechanism for the stratosphere, Geophys. Res. Lett., 9(6), 605-608, 1982.

Danielsen, E. F.: In situ evidence of rapid, vertical, irreversible transport of lower tropospheric air into the lower stratosphere by convective cloud turrets and by large scale up welling in tropical cyclones, J. Geophys. Res., 98, 8665-8681, 1993.

de Reus, M., Borrmann, S., Bansemer, A., Heymsfield, A. J., Weigel, R., Schiller, C., Mitev, V., Frey, W., Kunkel, D., Kürten, A., Curtius, J., Sitnikov, N. M., Ulanovsky, A., and Ravegnani, F.: Evidence for ice particles in the tropical stratosphere from insitu measurements, Atmos. Chem. Phys., 9, 6775-6792, 2009, http://www.atmos-chem-phys.net/9/6775/2009/.

Deshler, T., Hervig, M. E., Hofmann, D. J., Rosen, J. M., and Liley, J. B.: Thirty years of in situ stratospheric aerosol size distribution measurements from Laramie, Wyoming (41 N), using balloon-borne instruments, J. Geophys. Res., 108(D5), 4167, doi:10.1029/2002JD002514, 2003.

Di Donfrancesco, G., Cairo, F., Buontempo, C., Adriani, A., Viterbini, M., Snels, M., Morbidini, R., Piccolo, F., Cardillo, F., Pommereau, J. P., and Garnier, A.: Balloonborne lidar for cloud physics studies, Appl. Optics, 45, 1-8, 2006.

Durry, G., Amarouche, N., Zéninari, V., Parvitte, B., Lebarbu, T., and Ovarlez, J.: In situ sensing of the middle atmosphere with balloonborne near-infrared laser diodes, Spectrochim. Acta A, 60(4), 3371-3379, 2004.

Ern, M., Preusse, P., Krebsbach, M., Mlynczak, M. G., and Russell
III, J. M.: Equatorial wave analysis from SABER and ECMWF temperatures, Atmos. Chem. Phys., 8, 845-869, 2008, http://www.atmos-chem-phys.net/8/845/2008/.

Fischer, H., Birk, M., Blom, C., Carli, B., Carlotti, M., von Clarmann, T., Delbouille, L., Dudhia, A., Ehhalt, D., Endemann, M., Flaud, J. M., Gessner, R., Kleinert, A., Koopman, R., Langen, J., Lpez-Puertas, M., Mosner, P., Nett, H., Oelhaf, H., Perron, G., Remedios, J., Ridolfi, M., Stiller, G., and Zander, R.: MIPAS: an instrument for atmospheric and climate research, Atmos. Chem. Phys., 8, 2151-2188, 2008,

http://www.atmos-chem-phys.net/8/2151/2008/.

Franz, P. and Röckmann, T.: High-precision isotope measurements of $\mathrm{H}_{2}^{16} \mathrm{O}, \mathrm{H}_{2}^{17} \mathrm{O}, \mathrm{H}_{2}^{18} \mathrm{O}$, and the $\Delta^{17} \mathrm{O}$-anomaly of water vapor in the southern lowermost stratosphere, Atmos. Chem. Phys., 5, 2949-2959, 2005,

http://www.atmos-chem-phys.net/5/2949/2005/.

Fueglistaler, S., Dessler, A. E., Dunkerton, T. J., Folkins, I., Fu, Q., and Mote, P. W. : The tropical tropopause layer, Rev. Geophys., 47, RG1004, doi:10.1029/2008RG000267, 2009.

Gettelman, A., Salby, M. L., and Sassi, F.: The distribution and influence of convection in the tropical tropopause region, J. Geophys. Res., 107, ACL-61-12, doi:10.1029/2001JD001048, 2002.

Gettelman, A., Kinnison, D. E., Dunkerton, T. J., and Brasseur, G. P.: Impact of monsoon circulations on the upper troposphere and lower stratosphere, J. Geophys. Res., 109, D22101, doi:10.1029/2004JD004878, 2004.

Gostlow, B., Robinson, A. D., Harris, N. R. P., O’Brien, L. M., Oram, D. E., Mills, G. P., Newton, H. M., and Pyle, J. A.: ?Dirac: an autonomous instrument for halocarbon measurements, Atmos. Meas. Tech. Discuss., 2, 2123-2159, 2009,

http://www.atmos-meas-tech-discuss.net/2/2123/2009/.

Grosvenor, D. P., Choularton, T. W., Coe, H., and Held, G.: A study of the effect of overshooting deep convection on the water content of the TTL and lower stratosphere from Cloud Resolving Model simulations, Atmos. Chem. Phys., 7, 4977-5002, 2007, http://www.atmos-chem-phys.net/7/4977/2007/.

Hall, N. M. J. and Peyrillé, P.: Dynamics of the West African monsoon, J. Phys. IV France, 139, 81-99, 2006.

Highwood, E. J. and Hoskins, B. J.: The tropical tropopause, Q. J. Roy. Meteorol. Soc., 124, 1579-1604, 1998.

Hoffmann, L., Weigel, K., Spang, R., Schroeder, S., Arndt, K., Lehmann, C., Kaufmann, M., Ern, M., Preusse, P., Stroh, F., and Riese, M.: CRISTA-NF measurements of water vapor during the SCOUT-O $_{3}$ Tropical Aircraft Campaign, Adv. Space Res., 43, 74-81, doi:10.1016/j.asr.2008.03.018, 2009.

Homan, C. D., Volk, C. M., Kuhn, A. C., Werner, A., Baehr, J., Viciani, S., Ulanovski, A., and Ravegnani, F.: Tracer measurements in the tropical tropopause layer during the AMMA/SCOUT-O3 aircraft campaign, Atmos. Chem. Phys. Discuss., 9, 2504925084, 2009 http://www.atmos-chem-phys-discuss.net/9/25049/2009/.

Huntrieser, H., Schlager, H., Roiger, A., Lichtenstern, M., Schumann, U., Kurz, C., Brunner, D., Schwierz, C., Richter, A., and Stohl, A.: Lightning-produced $\mathrm{NO}_{\mathrm{x}}$ over Brazil during TROCCINOX: airborne measurements in tropical and subtropical thunderstorms and the importance of mesoscale convective systems, Atmos. Chem. Phys., 7, 2987-3013, 2007, http://www.atmos-chem-phys.net/7/2987/2007/.

Iannone, R. Q., Kassi, S., Jost, H.-J., Chenevier, M., Romanini, 
D., Meijer, H. A. J., Dhaniyala, S., Snels, M., and Kerstel E. R. T.: Development and airborne operation of a compact water isotope ratio infrared spectrometer, Isotopes in Environmental and Health Studies, 1, 99999, doi:10.1080/10256010903172715, 2009.

Janicot, S., Thorncroft, C. D., Ali, A., Asencio, N., Berry, G., Bock, O., Bourles, B., Caniaux, G., Chauvin, F., Deme, A., Kergoat, L., Lafore, J.-P., Lavaysse, C., Lebel, T., Marticorena, B., Mounier, F., Nedelec, P., Redelsperger, J.-L., Ravegnani, F., Reeves, C. E., Roca, R., de Rosnay, P., Schlager, H., Sultan, B., Tomasini, M., Ulanovsky, A., and ACMAD forecasters team: Large-scale overview of the summer monsoon over West Africa during the AMMA field experiment in 2006, Ann. Geophys., 26, 25692595, 2008,

http://www.ann-geophys.net/26/2569/2008/.

Kaiser, J., Engel, A., Borchers, R., and Röckmann, T.: Probing stratospheric transport and chemistry with new balloon and aircraft observations of the meridional and vertical $\mathrm{N}_{2} \mathrm{O}$ isotope distribution, Atmos. Chem. Phys., 6, 3535-3556, 2006,

http://www.atmos-chem-phys.net/6/3535/2006/.

Kerstel, E. R. T., Iannone, R. Q., Chenevier, M., Kassi, S., Jost, H.J., and Romanini, D.: A water isotope (2H, 17O, and 18O) spectrometer based on optical-feedback cavity enhanced absorption for in-situ airborne applications, Appl. Phys. B, 85(2-3), 397406, 2006.

Khaykin, S., Pommereau, J.-P., Korshunov, L., Yushkov, V., Nielsen, J., Larsen, N., Christensen, T., Garnier, A., Lukyanov, A., and Williams, E.: Hydration of the lower stratosphere by ice crystal geysers over land convective systems, Atmos. Chem. Phys., 9, 2275-2287, 2009,

http://www.atmos-chem-phys.net/9/2275/2009/.

Kylling, A., Danielsen, T., Blumthaler, M., Schreder, J., and Johnsen, B.: Twilight tropospheric and stratospheric photodissociation rates derived from balloon borne radiation measurements, Atmos. Chem. Phys., 3, 377-385, 2003,

http://www.atmos-chem-phys.net/3/377/2003/.

Kaiser, J., Engel, A., Borchers, R., and Röckmann, T.: Probing stratospheric transport and chemistry with new balloon and aircraft observations of the meridional and vertical $\mathrm{N}_{2} \mathrm{O}$ isotope distribution, Atmos. Chem. Phys., 6, 3535-3556, 2006, http://www.atmos-chem-phys.net/6/3535/2006/.

Lebel, T., Parker, D. J., Flamant, C., Bourles, B., Marticorena, B., Mougin, E., Peugeot, C., Haywood, J. M., Polcher, J., Redelsperger, J.-L., and Thorncroft, C. D.: The AMMA field campaigns, Multiscale and multidisciplinary observations in the West African region, Q. J. Roy. Meteorol. Soc., 88, 311-320, 2009.

Liu, C. and Zipser, E. J.: Global distribution of convection penetrating the tropical tropopause, J. Geophys. Res., 110, D23104, doi:10.1029/2005JD006063, 2005.

Marécal, V., Durry, G., Longo, K., Freitas, S., Rivire, E. D., and Pirre, M.: Mesoscale modelling of water vapour in the tropical UTLS: two case studies from the HIBISCUS campaign, Atmos. Chem. Phys., 7, 1471-1489, 2007,

http://www.atmos-chem-phys.net/7/1471/2007/.

Morel, C. and Senesi, A.: A climatology of mesoscale convective systems over Europe using satellite infrared imagery, I: Methodology, Q. J. Roy. Meteorol. Soc., 128(584), 1953-1971, 2002.

Nielsen, J. K., Larsen, N., Cairo, F., Di Donfrancesco, G., Rosen, J. M., Durry, G., Held, G., and Pommereau, J. P.: Solid particles in the tropical lowest stratosphere, Atmos. Chem. Phys., 7, 685695, 2007,

http://www.atmos-chem-phys.net/7/685/2007/.

Parker, D. J., Thorncroft, C. D., Burton, R. R., and Diongue-Niang, A.: Analysis of the African Easterly Jet, using aircraft observations from the JET2000 experiment, Q. J. Roy. Meteorol. Soc., 131, 1461-1482, 2005a.

Parker, D. J., Burton, R. R., Diongue-Niang, A., Ellis, R. J., Felton, M., Taylor, C. M., Thorncroft, C. D., Bessemoulin, P., and Tompkins, A. M.: The diurnal cycle of the West African monsoon circulation, Q. J. Roy. Meteorol. Soc., 131, 2839-2860, 2005 b.

Parker, D. J., Fink, A., Janicot, S., Ngamini, J.-B., Douglas, M., Afiesimama, E., Agusti-Panareda, A., Beljaars, A., Dide, F., Diedhiou, A., Lebel, T., Polcher, J., Redelsperger, J.-L., Thorncroft, C., and Ato Wilson G.: 2008: The AMMA radiosonde program and its implications for the future of atmospheric monitoring over Africa, B. Am. Meteorol. Soc., 89, 1015-1027, 2009.

Plumb, R. A.: A tropical pipe model of stratospheric transport, J. Geophys. Res., 101(D2), 3957-3972, 1996.

Pommereau, J.-P., Garnier, A., Held, G., Gomes, A.-M., Goutail, F., Durry, G., Borchi, F., Hauchecorne, A., Montoux, N., Cocquerez, P., Letrenne, G., Vial, F., Hertzog, A., Legras, B., Pisso, I., Pyle, J. A., Harris, N. R. P., Jones, R. L., Robinson, A., Hansford, G., Eden, L., Gardiner, T., Swann, N., Knudsen, B., Larsen, N., Nielsen, J., Christensen, T., Cairo, F., Pirre, M., Marécal, V., Huret, N., Rivière, E., Coe, H., Grosvenor, D., Edvarsen, K., Di Donfrancesco, G., Ricaud, P., Berthelier, J.-J., Godefroy, M., Seran, E., Longo, K., and Freitas, S.: An overview of the HIBISCUS campaign, Atmos. Chem. Phys. Discuss., 7, 2389-2475, 2007 ,

http://www.atmos-chem-phys-discuss.net/7/2389/2007/.

Pommereau, J.-P. and Held, G.: Is there a stratospheric fountain?, Atmos. Chem. Phys. Discuss., 7, 8933-8950, 2007,

http://www.atmos-chem-phys-discuss.net/7/8933/2007/.

Pommereau, J.-P. and Piquard, J.: Ozone and nitrogen dioxide vertical distributions by UV-visible solar occultation from balloons, Geophys. Res. Lett., 21(13), 1227-1230, 1994.

Prata, A. J., Carn, S. A., Stohl, A., and Kerkmann, J.: Long range transport and fate of a stratospheric volcanic cloud from Soufrière Hills volcano, Montserrat, Atmos. Chem. Phys., 7, 5093-5103, 2007, http://www.atmos-chem-phys.net/7/5093/2007/.

Pundt, I., Pommereau, J.-P., Chipperfield, M. P., Van Roozendael, M., and Goutail, F.: Climatology of the stratospheric BrO vertical distribution by balloon-borne UVvisible spectrometry, J. Geophys. Res., 107(D24), 4806, doi:10.1029/2002JD002230, 2002.

Real, E., Orlandi, E., Law, K. S., Fierli, F., Josset, D., Cairo, F., Schlager, H., Borrmann, S., Kunkel, D., Volk, M., McQuaid, J. B., Stewart, D. J., Lee, J., Lewis, A., Hopkins, J. R., Ravegnani, F., Ulanovski, A., and Liousse, C.: Cross-hemispheric transport of central African biomass burning pollutants: implications for downwind ozone production, Atmos. Chem. Phys. Discuss., 9, 17385-17427, 2009, http://www.atmos-chem-phys-discuss.net/9/17385/2009/.

Redelsperger, J.-L., Thorncroft, C. D., Diedhiou, A., Lebel, T., Parker, D. J., and Polcher, J.: African Monsoon Multidisciplinary Analysis: An International Research Project and Field Campaign, B. Am. Meteorol. Soc., 87, 1739-1746, 2006. 
Ricaud, P., Barret, B., Attié, J.-L., Motte, E., Le Flochmoën, E., Teyssèdre, H., Peuch, V.-H., Livesey, N., Lambert, A., and Pommereau, J.-P.: Impact of land convection on tropospherestratosphere exchange in the tropics, Atmos. Chem. Phys., 7, 5639-5657, 2007,

http://www.atmos-chem-phys.net/7/5639/2007/.

Ricaud, P., Pommereau, J.-P., Attié, J.-L., Le Flochmoën, E., El Amraoui, L., Teyssèdre, H., Peuch, V.-H., Feng, W., and Chipperfield, M. P.: Equatorial transport as diagnosed from nitrous oxide variability, Atmos. Chem. Phys., 9, 8173-8188, 2009, http://www.atmos-chem-phys.net/9/8173/2009/.

Robinson, A. D., McIntyre, J., Harris, N. R. P., Pyle, J. A., Simmonds, P. G., and Danis, F.: A lightweight balloon-borne gas chromatograph for in-situ measurements of atmospheric halocarbons, Rev. Sci. Instrum., 71, 4553-4560, 2000.

Rosen, J. M. and Kjome, N. T.: Backscattersonde - A new instrument for atmospheric aerosol research, Appl. Optics, 30, 15521561, 1991.

Rossow W. B., Pearl C.: 22-Year survey of tropical convection penetrating into the lower stratosphere, Geophys. Rel. Lett., 34, L04803, doi:10.1029/2006GL028635, 2007.

Schiller, C., Krämer, M., Afchine, A., Spelten, N., and Sitnikov, N.: The ice water content of Arctic, mid latitude and tropical cirrus, J. Geophys. Res., 113, D24208, doi:10.1029/2008JD010342, 2008.

Schiller, C., Grooß, J.-U., Konopka, P., Plöger, F., Silva dos Santos, F. H., and Spelten, N.: Hydration and dehydration at the tropical tropopause, Atmos. Chem. Phys., 9, 9647-9660, 2009, http://www.atmos-chem-phys.net/9/9647/2009/.

Shur, G. H., Sitnikov, N. M., and Drynkov, A. V.: A Mesoscale Structure of Meteorological Fields in the Tropopause Layer and in the Lower Stratosphere over the Southern Tropics (Brazil), Russ. Meteorol. Hydrol., 32, 487-494, 2007.

Simões, F., Berthelier, J.-J., Godefroy, M., and Yahi, S.: Observation and modeling of the Earth-ionosphere cavity electromagnetic transverse resonance and variation of the D-region electron density near sunset, Geophys. Res. Lett., L14816, doi:10.1029/2009 GL039286, 2009.

Sitnikov, N., Yushkov, V., Afchine, A. A., Korshunov, L. I., Astakhov, V. I., Ulanovskii, A. E., Krämer, M., Mangold, M. A., Schiller, C., Ravegnani, F. : The FLASH instrument for water vapor measurements on board the high-altitude airplane, Russian Journal on Instruments and Experimental Techniques, 50(1), 113-121, 2007.

Slingo, A., Bharmal, N. A., Robinson, G. J., Settle, J. J., Allan, R. P., White, H. E., Lamb, P. J., Lele, M. I., Turner, D. D., McFarlane, S., Kassianov, E., Barnard, J., Flynn, C., and Miller, M.: Overview of observations from the RADAGAST experiment in Niamey, Niger: Meteorology and thermodynamic variables, J. Geophys. Res., 113, D00E01, doi:10.1029/2008JD009909, 2008.

Schmitt, J.: Construction and testing of an in-situ NO/NO $\mathrm{NO}_{\mathrm{y}}$ measuring system aboard the high-altitude research aircraft M55Geoophysica, PhD thesis, University Munich, DLR Research Report, ISRN-DLR-FB-2003-21, 2003.

Smit, H. G. J., Straeter W., Johnson B. J., Oltmans S. J., Davies J., Tarasick D. W.,Hoegger B., Stubi R., Schmidlin F.J.,Northam T., Thompson A. M., Witte J. C., Boyd I., Posny F.: Assessment of the performance of ECC-ozonesondes under quasi-flight condi- tions in the environmental simulation chamber: Insights from the Juelich Ozone Sonde Intercomparison Experiment (JOSIE), J. Geophys. Res., 112, D19306, doi:10.1029/2006JD007308, 2007. Spang, R., Hoffmann, L., Kullmann, A., Olschewski, F., Preusse, P., Knieling, P., Schroeder, S., Stroh, F., Weigel, K., and Riese, M.: High resolution limb observations of clouds by the CRISTA$\mathrm{NF}$ experiment during the $\mathrm{SCOUT}-\mathrm{O}_{3}$ tropical aircraft campaign, Adv. Space Res., 42, 1765-1775, doi:10.1016/j.asr.2007.09.036, 2008.

Sultan, B. and Janicot, S.: Abrupt shift of the ITCZ over West Africa and intraseasonal variability, Geophys. Res. Lett., 27, 3353-3356, 2000

Sultan, B.,Janicot S.: The West African Monsoon Dynamics. Part II: The "Preonset" and "Onset" of the Summer Monsoon, J. Climate, 16, 3407-3427,2003.

Stefanutti, L., MacKenzie, A. R., Balestri, S., Khattatov, V., Fiocco, G., Kyrö, E., and Peter, T.: Airborne Polar Experiment-Polar Ozone, Leewaves, Chemistry, and Transport (APE-POLECAT): Rationale, road map and summary of measurements, J. Geophys. Res., 104(D19), 23941-23959, 1999.

Suomi, V. E. and Kuhn, P. M.: An economical net radiometer, Tellus, 10, 160-163, 1958.

Tucker, C. J., Pinzon, J. E., Brown, M. E., Slayback, D. A., Pak, E. W., Mahoney, R., Vermote, E. F., El Saleous, N.: An extended AVHRR 8-km NDVI dataset compatible with MODIS and SPOT vegetation NDVI data, Int. J. Remote Sens., 26(20), 4485-4498, 2005.

Vernier, J. P., Pommereau, J. P., Garnier, A., Pelon, J., Larsen, N., Nielsen, J., Christensen, T., Cairo, F., Thomasson, L. W., Leblanc, T., and McDermid, I. S.: Tropical stratospheric aerosol layer from CALIPSO lidar observations, J. Geophys. Res., 114, D00H10, doi:10.1029/2009JD011946, 2009.

Viciani, S., D’Amato, F., Mazzinghi, P., Castagnoli, F., Toci, G., and Werle, P.: A cryogenically operated laser diode spectrometer for airborne measurement of stratospheric trace gases, Appl. Phys. B, 90, 581-592, 2008.

Voigt, C., Schlager, H., Luo, B. P., Dörnbrack, A., Roiger, A., Stock, P., Curtius, J., Vössing, H., Borrmann, S., Davies, S., Konopka, P., Schiller, C., Shur, G., and Peter, T.: Nitric Acid Trihydrate (NAT) formation at low NAT supersaturation in Polar Stratospheric Clouds (PSCs), Atmos. Chem. Phys., 5, 13711380, 2005, http://www.atmos-chem-phys.net/5/1371/2005/.

Voigt, C., Schlager, H., Roiger, A., Stenke, A., de Reus, M., Borrmann, S., Jensen, E., Schiller, C., Konopka, P., and Sitnikov, N.: Detection of reactive nitrogen containing particles in the tropopause region - evidence for a tropical nitric acid trihydrate (NAT) belt, Atmos. Chem. Phys., 8, 7421-7430, 2008, http://www.atmos-chem-phys.net/8/7421/2008/.

Volk, C. M., Riediger, O., Strunk, M., Schmidt, U., Ravegnani, F., Ulanovsky, A., and Rudakov, V.: In situ Tracer Measurements in the Tropical Tropopause Region During APE-THESEO, Eur. Comm. Air Pollut. Res. Report, 73, 661-664, 2000.

von Hobe, M., Groo, J.-U., Müller, R., Hrechanyy, S., Winkler, U., and Stroh, F.: A re-evaluation of the $\mathrm{ClO} / \mathrm{Cl}_{2} \mathrm{O}_{2}$ equilibrium constant based on stratospheric in-situ observations, Atmos. Chem. Phys., 5, 693-702, 2005, http://www.atmos-chem-phys.net/5/693/2005/.

Weigel, R., Hermann, M., Curtius, J., Voigt, C., Walter, S., Böttger, 
T., Lepukhov, B., Belyaev, G., and Borrmann, S.: Experimental characterization of the COndensation PArticle counting System for high altitude aircraft-borne application, Atmos. Meas. Tech., 2, 243-258, 2009,

http://www.atmos-meas-tech.net/2/243/2009/.

Williams, E., Nathou, N., Hicks, E., Pontikis, C., Russell, B., Miller, M., and Bartholomew, M. J.: The Electrification of DustLofting Gust Fronts ("Haboobs") in the Sahel, Atmos. Res., 91, 292-298, 2009.

Yushkov, V., Merkulov, S., and Astakhov, V.: Optical balloon hygrometer for upper stratosphere and stratosphere water vapour measurements, in: Optical remote sensing of the atmosphere and clouds, edited by: Wang, J., Wu, B., Ogawa, T., and Guans, Z.H., Proc. SPIE, 3501, 439-445, 1998.
Yushkov, V., Oulanovsky, A., Lechenuk, N., Roudakov, I., Arshinov, K., Tikhonov, F., Stefanutti, L., Ravegnani, F., Bonafé, U., and Georgiadis, T.: A Chemiluminescent Analyzer for Stratospheric Measurements of the Ozone Concentration (FOZAN), J. Atmos. Ocean. Tech., 16, 1345-1350, 1999.

Zipser, E. J., Cecil, D. J., Liu, C., Nesbitt, S. W., and Yorty, D. P.: Where are the most intense thunderstorms on Earth? B. Am. Meteorol. Soc., 1057-1071, 2006.

Zöger, M., Afchine, A., Eicke, N., Gerhards, M. T., Klein, E., McKenna, D. S., Mörschel, U., Schmidt, U., Tan, V., Tuitjer, F., Woyke, T., and Schiller, C.: Fast in situ stratospheric hygrometers: A new family of balloonborne and airborne Lyman-a photofragment fluorescence hygrometers, J. Geophys. Res., 104, 1807-1816, 1999. 